\title{
Rhizosphere to the atmosphere: contrasting methane pathways, fluxes, and geochemical drivers across the terrestrial-aquatic wetland boundary
}

\author{
Luke C. Jeffrey ${ }^{1,2}$, Damien T. Maher ${ }^{1,2,3}$, Scott G. Johnston ${ }^{1}$, Kylie Maguire ${ }^{1}$, Andrew D. L. Steven ${ }^{4}$, and \\ Douglas R. Tait ${ }^{1,2}$ \\ ${ }^{1}$ SCU Geoscience, Southern Cross University, P.O. Box 157, Lismore, NSW 2480, Australia \\ ${ }^{2}$ National Marine Science Centre, Southern Cross University, P.O. Box 4321, Coffs Harbour, NSW 2450, Australia \\ ${ }^{3}$ School of Environment, Science and Engineering, Southern Cross University, Lismore, NSW 2480, Australia \\ ${ }^{4}$ CSIRO Oceans and Atmosphere, Queensland Biosciences Precinct, University of Queensland, 306 Carmody Rd, \\ St Lucia, Brisbane 4067, Australia
}

Correspondence: Luke C. Jeffrey (luke.jeffrey@scu.edu.au)

Received: 15 January 2019 - Discussion started: 22 January 2019

Revised: 29 March 2019 - Accepted: 2 April 2019 - Published: 29 April 2019

\begin{abstract}
Although wetlands represent the largest natural source of atmospheric $\mathrm{CH}_{4}$, large uncertainties remain regarding the global wetland $\mathrm{CH}_{4}$ flux. Wetland hydrological oscillations contribute to this uncertainty, dramatically altering wetland area, water table height, soil redox potentials, and $\mathrm{CH}_{4}$ emissions. This study compares both terrestrial and aquatic $\mathrm{CH}_{4}$ fluxes in permanent and seasonal remediated freshwater wetlands in subtropical Australia over two field campaigns, representing differing hydrological and climatic conditions. We account for aquatic $\mathrm{CH}_{4}$ diffusion and ebullition rates and plant-mediated $\mathrm{CH}_{4}$ fluxes from three distinct vegetation communities, thereby examining diel and intrahabitat variability. $\mathrm{CH}_{4}$ emission rates were related to underlying sediment geochemistry. For example, distinct negative relationships between $\mathrm{CH}_{4}$ fluxes and both $\mathrm{Fe}(\mathrm{III})$ and $\mathrm{SO}_{4}^{2-}$ were observed. Where sediment $\mathrm{Fe}(\mathrm{III})$ and $\mathrm{SO}_{4}^{2-}$ were depleted, distinct positive trends occurred between $\mathrm{CH}_{4}$ emissions and $\mathrm{Fe}$ (II) / acid volatile sulfur (AVS). Significantly higher $\mathrm{CH}_{4}$ emissions $(p<0.01)$ in the seasonal wetland were measured during flooded conditions and always during daylight hours, which is consistent with soil redox potential and temperature being important co-drivers of $\mathrm{CH}_{4}$ flux. The highest $\mathrm{CH}_{4}$ fluxes were consistently emitted from the permanent wetland ( 1.5 to $10.5 \mathrm{mmol} \mathrm{m}^{-2} \mathrm{~d}^{-1}$ ), followed by the Phragmites australis community within the seasonal wetland ( 0.8 to $2.3 \mathrm{mmol} \mathrm{m}^{-2} \mathrm{~d}^{-1}$ ), whilst the lowest $\mathrm{CH}_{4}$
\end{abstract}

fluxes came from a region of forested Juncus spp. (-0.01 to $0.1 \mathrm{mmol} \mathrm{m}^{-2} \mathrm{~d}^{-1}$ ), which also corresponded to the highest sedimentary $\mathrm{Fe}(\mathrm{III})$ and $\mathrm{SO}_{4}^{2-}$. We suggest that wetland remediation strategies should consider geochemical profiles to help to mitigate excessive and unwanted methane emissions, especially during early system remediation periods.

\section{Introduction}

Wetlands are considered one of the most valuable ecosystems on Earth (Costanza et al., 2014) and may be classified as both permanently inundated (i.e. lakes and shallow waters) and seasonally inundated (i.e. vegetated) biomes. They are biodiversity hotspots that provide ecosystem services such as water filtration, sediment trapping, floodwater retention, and carbon (C) storage (Bianchi, 2007). Wetlands account for $\sim 5.5 \%$ of terrestrial surfaces (Melton et al., 2013) and have been estimated to store $\sim 4 \%$ (Bridgham et al., 2014) to $30 \%$ (Mitsch et al., 2013) of Earth's estimated $2500 \mathrm{Pg}$ soil C pool (Lal, 2008). Pristine wetlands have long been considered net $\mathrm{C}$ sinks due to their high rates of productivity and low rates of decomposition (Petrescu et al., 2015); however, due to their waterlogged nature and anaerobic soils, wetlands are ideal environments for the production of methane $\left(\mathrm{CH}_{4}\right)$, a potent greenhouse gas. As such, wet- 
lands are recognised as Earth's largest natural source of $\mathrm{CH}_{4}$ to the atmosphere $\left(185 \pm 21 \mathrm{Tg} \mathrm{C} \mathrm{yr}^{-1}\right)$ (Saunois et al., 2016).

Resolving the drivers, pathways, and effects of seasonal weather oscillations on wetland $\mathrm{CH}_{4}$ sink or source behaviours is important to enable more accurate climate model projections and to reduce uncertainties in the global wetland $\mathrm{CH}_{4}$ budget (Kirschke et al., 2013; Saunois et al., 2016). Weather oscillations affect the total wetland areal extent and inundation periods, with wet conditions facilitating anaerobic conditions favouring methanogenesis, while the opposite is seen during dry periods, which potentially mitigates $\mathrm{CH}_{4}$ emissions (Wang et al., 1996; Whiting and Chanton, 2001). Mitsch et al. (2013) estimated that the average ratio of freshwater wetland $\mathrm{CO}_{2}$ sequestration to $\mathrm{CH}_{4}$ emissions was $25.5: 1$, though this was later refuted by Bridgham et al. (2014). As $\mathrm{CH}_{4}$ is 34 times more potent than carbon dioxide $\left(\mathrm{CO}_{2}\right)$ over a 100-year timescale (Stocker et al., 2013), this suggests that many freshwater wetlands may have a net positive radiative forcing effect on climate (Petrescu et al., 2015; Hemes et al., 2018). However, variability in geomorphology, wetland maturity, salinity, and underlying geochemical composition contributes to variable $\mathrm{CH}_{4}$ dynamics (Whiting and Chanton, 2001; Bastviken et al., 2011; Poffenbarger et al., 2011). The lack of latitudinally resolved wetland $\mathrm{CH}_{4}$ emission data, the limited number of studies constraining the multiple wetland $\mathrm{CH}_{4}$ flux pathways (i.e. ebullition, diffusion, and plant-mediated), and the ongoing anthropogenic conversion of wetland systems (Bartlett and Harriss, 1993; Neubauer and Megonigal, 2015; Saunois et al., 2016) further contribute to uncertainties around $\mathrm{CH}_{4}$ regional- to global-scale budgets.

Extensive clearing and drainage of many coastal wetlands has occurred over the previous 2 centuries in order to accommodate agriculture, aquaculture, and urban development (Armentano and Menges, 1986; White et al., 1997; Villa and Bernal, 2018). Drained wetlands can lead to rapid soil organic matter oxidation and transform systems to net $\mathrm{CO}_{2}$ sources (Deverel et al., 2016; Pereyra and Mitsch, 2018). Drainage systems can also reduce wetland inundation periods and alter sediment redox-dependant geochemistry and microbially mediated reactions (Johnston et al., 2014), particularly those involving bioavailable iron ( $\mathrm{Fe}(\mathrm{III})$ ), sulfate $\left(\mathrm{SO}_{4}^{2-}\right)$, and nitrate $\left(\mathrm{NO}_{3}^{-}\right)$. Importantly, anaerobic carbon metabolism employing these terminal electron acceptors ( $\mathrm{Fe}(\mathrm{III}), \mathrm{SO}_{4}^{2-}, \mathrm{NO}_{3}^{-}$) competes thermodynamically with methanogenic bacteria and Archaea and can thereby inhibit $\mathrm{CH}_{4}$ production (Lal, 2008; Burdige, 2012; á Norði and Thamdrup, 2014; Karimian et al., 2018). With increasing value placed on the ecosystem services provided by wetlands, many degraded systems are now undergoing remediation and re-flooding (Johnston et al., 2014). However, the ecosystem benefits, such as enhanced biodiversity and water quality, may come at a price in the form of higher initial $\mathrm{CH}_{4}$ flux rates and predicted net radiative forcing for several centuries post-remediation - thus posing a "biogeochemical compromise" (Hemes et al., 2018).

Within Australia, it has been estimated that more than $50 \%$ of natural wetlands have been lost to land use change, drainage, and degradation since European settlement (ANCA, 1995; Finlayson and Rea, 1999). By comparing and reviewing pristine Australian wetland carbon stocks to drained sites and greenhouse gas dynamics, Page and Dalal (2011) estimated that through biomass loss, enhanced soil respiration, $\mathrm{N}_{2} \mathrm{O}$ production, and a reduction in $\mathrm{CH}_{4}$ emissions, Australian wetland loss equated to $\sim 1.2 \mathrm{Pg}$ of $\mathrm{CO}_{2}$ equivalent emitted to the atmosphere. Much of eastern Australia's freshwater coastal wetlands are underlain by Holocene-derived sulfidic sediments (i.e. pyrite $-\mathrm{Fe}_{2} \mathrm{~S}$, known as coastal acid sulfate soils; CASSs) formed during periods of higher sea levels (Walker, 1972; White et al., 1997). When CASSs are drained, pyrite is oxidised, producing sulfuric acid $\left(\mathrm{H}_{2} \mathrm{SO}_{4}\right)$. This results in highly acidic soils with pH levels as low as 3 (Sammut et al., 1996; Johnston et al., 2014). After rainfall events, groundwater transports $\mathrm{H}_{2} \mathrm{SO}_{4}$ from the CASS landscapes into nearby creeks and estuaries (Sammut et al., 1996). The low pH groundwater discharge also mobilises iron and aluminium, fuels aquatic deoxygenation, and can lead to large fish kills and degradation of infrastructure (White et al., 1997; Johnston et al., 2003; Jeffrey et al., 2016; Wong et al., 2010). Drained CASS wetlands typically contain abundant reactive $\mathrm{Fe}(\mathrm{III})$ and exhibit complex sulfur and Fe cycling (Burton et al., 2006, 2011; Boman et al., 2008). Wetland iron and sulfur cycling can profoundly influence $\mathrm{CH}_{4}$ production and consumption via a series of complex redox reactions coupled with organic matter mineralisation (Holmkvist et al., 2011; Sivan et al., 2014). As such, terminal electron acceptor availability is critical when considering wetland remediation and the biogeochemical compromise paradigm.

Here we assess $\mathrm{CH}_{4}$ emissions from a remediated freshwater CASS wetland in subtropical eastern Australia and compare fluxes from the permanent wetland and the adjacent seasonal wetland ecotypes. We hypothesise that wetland $\mathrm{CH}_{4}$ emissions will differ significantly between the campaigns and between the four wetland communities due to differences in soil chemistry, hydrology, and plant physiology. We account for three atmospheric flux pathways for methane; ebullition, diffusion, and plant-mediated fluxes over diel cycles and within different hydrological conditions. $\mathrm{CH}_{4}$ fluxes were also assessed in relation to the underlying soil properties, including sulfate, reactive iron III and iron II, acid volatile sulphur, chloride, and organic carbon. 


\section{Methods}

\subsection{Study site}

Cattai Wetlands are located on the mid-coast of New South Wales, Australia. The reserve covers 500 ha, featuring a shallow permanent wetland covering an area of approximately 16 ha that is adjacent to a seasonal wetland and floodplain located to the south (Fig. 1). Both sites discharge into the nearby Coopernook Creek, a tributary of the larger Manning River estuary. The site was extensively cleared and low-lying areas drained during the early 1900s in order to aid agriculture and development in the region. As a result of this anthropogenic drainage, the oxidation of CASS produced sulfuric acid and episodic acidic discharge to adjacent creeks for many years (Tulau, 1999). To ameliorate acidic discharge, the natural hydrology of the site was restored in 2003 through the decommissioning of agricultural drains and removal of floodgates. Re-flooding of the CASS landscape has reduced the production of sulfuric acid, acid discharge, and aluminium and iron mobilisation, hence improving the downstream water quality (GTCC, 2014).

The region receives a mean annual rainfall of $1180 \mathrm{~mm}$ with the majority falling during early autumn with an average maximal monthly rainfall occurring in March $(152 \mathrm{~mm})$. The lowest rainfall generally occurs during the winter months with average minimal rainfall during September $(60 \mathrm{~mm})$. Average minimum and maximum summer temperatures range from 17.6 to $29^{\circ} \mathrm{C}$ (January) and in winter range from 5.9 to $18.5^{\circ} \mathrm{C}$ (July) (BOM, 2018). The dominant vegetation type within the permanent wetland is an introduced water lily species (Nymphaea capensis), while the fringes of the wetland consist of wetland tree species: Casuarina spp. and Melaleuca quinquenervia. The seasonal wetland to the south is dominated by the sedge Juncus kraussii ("Juncus" from here on) and features scattered stands of Phragmites australis ("Phragmites" from here on) with areas of slightly higher elevation dominated by Juncus kraussii below Casuarina spp. ("Juncus-forest" from here on) (Fig. 1).

\subsection{The aquatic $\mathrm{CH}_{4}$ flux of the permanent wetland}

To quantify $\mathrm{CH}_{4}$ ebullition rates, up to 12 ebullition domes were deployed under two different hydrological conditions (detailed below) at $\sim 20 \mathrm{~m}$ intervals along a longitudinal transect, from the edge of the permanent wetland towards the centre. Each dome was carefully suspended below the water level by flotation rings, ensuring minimal disturbance of sediment and the water column. Gas samples were extracted from the headspace of each dome using a $300 \mathrm{~mL}$ gas-tight syringe at periods of $\sim 48 \mathrm{~h}$. The volume was recorded and each sample then diluted using ambient air (1:729 ratio) and analysed in situ using a using a manufacturer-calibrated cavity ring-down spectrometer (Picarro G2201-i) to determine $\mathrm{CH}_{4}$ concentrations (ppm). Diffusive $\mathrm{CH}_{4}$ fluxes from the permanent wetland were measured using a floating chamber with a portable greenhouse gas analyser (UGGA, Los Gatos Research). To account for spatial and temporal variability, measurements were conducted during both daytime and night-time, and sampling was within vegetated areas featuring lilies (Nymphaea capensis) that were only present during the second campaign, forested areas (Melaleuca spp.), and in areas where no aquatic vegetation was present (i.e. open water). A total of $39 \mathrm{CH}_{4}$ floating chamber incubations averaging $\sim 8 \mathrm{~min}$ in duration were recorded over the two campaigns, with 19 during $\mathrm{C} 1$ (nine at night) and 30 during $\mathrm{C} 2$ (12 at night). The average $r^{2}$ value of linear regressions of $\mathrm{CH}_{4}$ concentrations versus time during chamber incubations was $0.97 \pm 0.05$. One chamber measurement was disregarded as an outlier (as it was more than 3 times the standard deviation of the mean) and any chambers capturing ebullition bubbles (determined by a non-linear increase in concentration) were also disregarded. Examples of these, in addition to the ebullition and diffusive $\mathrm{CH}_{4}$ flux methods and measurements from the permanent wetland, have previously been reported elsewhere (Jeffrey et al., 2019).

\subsection{Plant-mediated $\mathrm{CH}_{4}$ fluxes}

Simultaneous time series chamber experiments were conducted over a minimum of $24 \mathrm{~h}$ to measure diel $\mathrm{CH}_{4}$ fluxes during each campaign from the three different wetland vegetation ecotypes. These ecotypes were Juncus kraussii, Phragmites australis, and Juncus kraussii amongst Casuarina spp. forest (Fig. 1). In each ecotype, three acrylic bases $(65 \times 65 \times$ $30 \mathrm{~cm}$ ) were installed 4 months before the first time series experiment to minimise disturbance to the sediment profile and vegetative rhizosphere. Vegetative flux chambers were constructed of an aluminium frame with clear Perspex walls and a roof that matched the areal footprint of the pre-inserted acrylic bases. The chambers were 100,150, and $50 \mathrm{~cm}$ high at Juncus, Phragmites, and Juncus-forest sites, respectively. The custom sizes were tailored for the different vegetation heights, whilst minimising chamber volume as much as possible. Each chamber was leak-tested under laboratory conditions prior to fieldwork

Before each field incubation, chambers were flushed with atmospheric air and then carefully lowered over the vegetation and onto the acrylic base, ensuring an airtight seal. A small fan circulated internal air within each chamber. Air within the chamber was pumped through a closed loop from the top of the chamber using gas tubing (BEV-A-Line), passing through a drying agent (Drierite desiccant), and then analysed in situ using a calibrated cavity ring-down spectrometers (Picarro G2201-i or Los Gatos), recording the flux rate of $\mathrm{CH}_{4}\left(\mathrm{ppm} \mathrm{s}^{-1}\right)$. The gas flow was returned near the base inside each vegetation chamber, closing the loop. Vegetation incubation times ranged from 6 to 15 min depending on the flux rate and were taken from triplicate chambers to account for heterogeneity within each ecotype. During the 

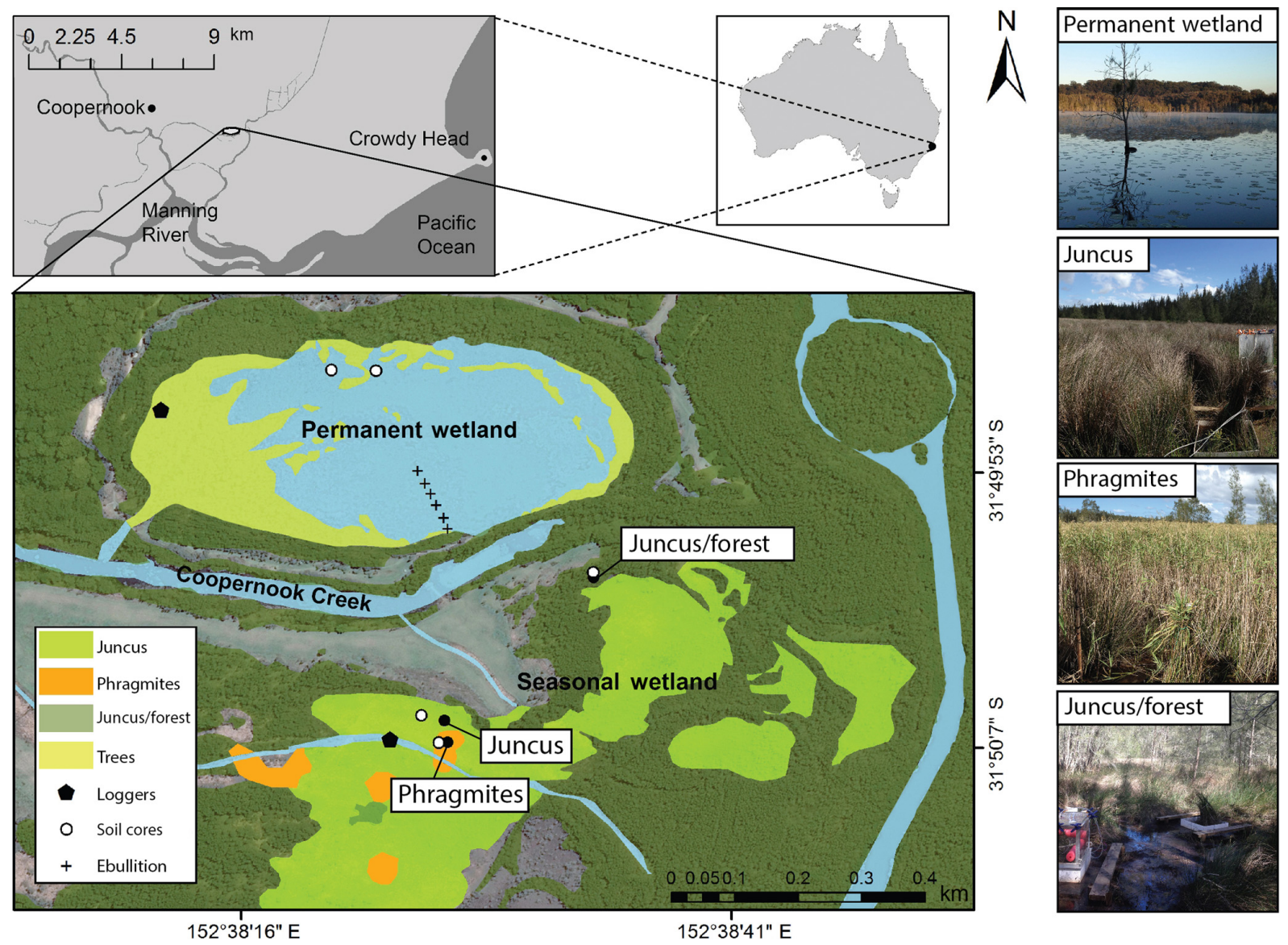

Figure 1. The seasonal wetland study sites consisting of Juncus (Juncus kraussii), Phragmites (Phragmites australis), and Juncus-forest (Juncus kraussii below Casuarina spp.); the permanent wetland and sediment coring sites, ebullition replicate transect, $24 \mathrm{~h}$ vegetation time series sites, and imagery of vegetation ecotypes.

first time series (C1), an average of $16.7 \pm 2.9$ daytime flux measurements (i.e. after sunrise) and 7.3 \pm 1.6 night-time (i.e. after sunset) were recorded within each habitat. During the second campaign (C2) an average of $27.7 \pm 2.9$ (daytime) and $10.3 \pm 1.5$ (night-time) flux measurements were recorded within each habitat. In addition, $\mathrm{CH}_{4}$ fluxes from the adjacent exposed soils or shallow overlying water at each site were also measured at $\sim 4 \mathrm{~h}$ intervals to determine the influence and role of plant-mediated $\mathrm{CH}_{4}$ fluxes compared to nonvegetated $\mathrm{CH}_{4}$ fluxes. Light and temperature loggers (Onset Hobo) measured the changes in diel air temperature $\left({ }^{\circ} \mathrm{C}\right)$ and photosynthetically active radiation (PAR) at each site.

\subsection{Soil geochemistry and redox conditions}

A water logger (Minidiver, Van Essen Instruments) was deployed in the permanent wetland before the first campaign to monitor changes in water depth $(\mathrm{cm})$ and temperature $\left({ }^{\circ} \mathrm{C}\right)$. Field $\mathrm{pH}\left(\mathrm{pH}_{\mathrm{F}}\right)$ and the redox potential $\left(\mathrm{Eh}_{\mathrm{F}}\right.$; reported against standard hydrogen electrode) were determined in situ by directly inserting the electrode into the soils $(5 \mathrm{~cm}$ of depth, eight replicates on average) at each site. A composite sampling approach (three cores) was used to collect sediment samples from each site to determine organic $\mathrm{C}$ content, $\mathrm{Fe}(\mathrm{III})_{\mathrm{HCl}}, \mathrm{Fe}(\mathrm{II})_{\mathrm{HCl}}, \mathrm{Cl}, \mathrm{SO}_{4}^{2-}$, and acid volatile sulfur (AVS). The cores were sampled in close proximity to the time series habitats ( 5 to $15 \mathrm{~m}$ ) in December 2016, but within the permanent wetland the cores were taken from elsewhere to avoid disturbance of the shallow water column and sediments. The cores were extracted by inserting a $4.0 \mathrm{~cm}$ diameter acrylic tube into the sediment to a depth of up to $50 \mathrm{~cm}$. Cores were immediately sectioned into $2 \mathrm{~cm}$ increments to a depth of $20 \mathrm{~cm}$, and $5 \mathrm{~cm}$ increments thereafter, ensuring higher vertical resolution in the organic-rich nearsurface sediments. Samples were immediately placed into airtight bags, then frozen within $12 \mathrm{~h}$ of collection at $-16^{\circ} \mathrm{C}$ in a portable freezer and transferred to $\mathrm{a}-80^{\circ} \mathrm{C}$ freezer in the laboratory.

For analysis, the frozen samples were thawed in an oxygen-free anaerobic chamber $\left(1 \%-5 \% \mathrm{H}_{2}\right.$ in $\left.\mathrm{N}_{2}\right)$ using an oxygen-consuming palladium $(\mathrm{Pd})$ catalyst. The defrosted samples were homogenised using a plastic spatula. AVS con- 
tent was determined by adding $1-2 \mathrm{~g}$ of wet sediment with $6 \mathrm{M} \mathrm{HCl}: 1 \mathrm{M} \mathrm{L-ascorbic} \mathrm{acid.} \mathrm{The} \mathrm{liberated} \mathrm{H}_{2} \mathrm{~S}$ was captured in $5 \mathrm{~mL}$ of $3 \% \mathrm{Zn}$ acetate in $2 \mathrm{M} \mathrm{NaOH}$ and then quantified using iodometric titration. The reactive $\mathrm{Fe}$ fractions were determined using a sequential extraction procedure optimised for acid sulfate soils based on Claff et al. (2010). Poorly crystalline solid-phase Fe(II) and Fe(III) were determined by extracting $2 \mathrm{~g}$ wet subsamples with cold $\mathrm{N}_{2}$-purged $1 \mathrm{M} \mathrm{HCl}$ for $4 \mathrm{~h}$. Aliquots of $0.45 \mu \mathrm{m}$ filtered extract were analysed for $\mathrm{Fe}(\mathrm{II})\left[\mathrm{Fe}(\mathrm{II})_{\mathrm{HCl}}\right]$ and total $\mathrm{Fe}\left[\mathrm{Fe}_{\mathrm{HCl}}\right]$ using the 1,10-phenanthroline method with the addition of hydroxylammonium chloride for total Fe (APHA, 2005). The Fe(III) $\left[\mathrm{Fe}(\mathrm{III})_{\mathrm{HCl}}\right]$ was determined by the difference of $\left[\mathrm{Fe}_{\mathrm{HCl}}\right]-$ $\left[\mathrm{Fe}(\mathrm{II})_{\mathrm{HCl}}\right]$. Total organic carbon (TOC) and total $\mathrm{S}\left(\mathrm{S}_{\mathrm{Tot}}\right)$ were determined via a LECO CNS-2000 carbon and sulfur analyser. Chloride and sulfate concentrations were measured using filtered $(0.45 \mu \mathrm{m})$ aliquot from a $1: 5$ water extract of freshly defrosted wet soil, as per Rayment and Higginson (1992), via ion chromatography using a Metrosep A Supp4-250 column, an RP2 guard column, and eluent containing $2 \mathrm{mM} \mathrm{NaHCO}_{3}, 2.4 \mathrm{mM} \mathrm{Na} \mathrm{CO}_{3}$, and $5 \%$ acetone, in conjunction with a Metrohm MSM module for background suppression.

\subsection{Calculations}

Both the air-water and vegetative $\mathrm{CH}_{4}$ fluxes were calculated for the chamber deployments in the permanent wetland and seasonal wetland using the equation

$F=\left(s\left(V / R T_{\text {air }} A\right)\right) t$,

where $s$ is the regression slope for each chamber incubation deployment (ppm s$\left.{ }^{-1}\right), V$ is the chamber volume $\left(\mathrm{m}^{3}\right), R$ is the universal gas constant $\left(8.205 \times 10^{-5} \mathrm{~m}^{3}\right.$ atm K $\left.\mathrm{K}^{-1} \mathrm{~mol}^{-1}\right)$, $T_{\text {air }}$ is the air temperature inside the chamber $(\mathrm{K}), A$ is the surface area of the chamber $\left(\mathrm{m}^{2}\right)$, and $t$ is the conversion factor from seconds to days and to millimoles. We assume that atmospheric pressure is $1 \mathrm{~atm}$. Ebullition rates $\left(E_{b}\right)$ $\left(\mathrm{mmol} \mathrm{m} \mathrm{m}^{-2} \mathrm{~d}^{-1}\right)$ were calculated using the equation

$E_{b}=\left(\left[\mathrm{CH}_{4}\right] \mathrm{CH}_{4 \mathrm{Vol}}\right) / A V_{\mathrm{m}} T_{\mathrm{d}}$,

where $\left[\mathrm{CH}_{4}\right]$ is the $\mathrm{CH}_{4}$ concentration in the collected gas (\%), $\mathrm{CH}_{4 \mathrm{Vol}}$ is the gas volume sampled (L), $A$ is the funnel area $\left(\mathrm{m}^{2}\right), V_{\mathrm{m}}$ is the molar volume of $\mathrm{CH}_{4}$ at in situ temperature $(\mathrm{L})$, and $T_{\mathrm{d}}$ is deployment time (days).

\subsection{Statistical analysis}

As the $\mathrm{CH}_{4}$ flux data was non-parametric we used a KruskalWallis one-way analysis of variance (ANOVA) on ranks to test for significant differences between each campaign, between flux pathways, and between diel variability, where $p<0.001$. Dunn's multiple pairwise comparisons were then used to analyse specific sample pairs $(p<0.05)$.

\section{Results}

Prior to the first campaign in April 2017 (C1), an extreme hot-drying summer period occurred (Fig. 2). This resulted in an average wetland water column temperature of $23.3 \pm$ $0.7^{\circ} \mathrm{C}$ and a water depth in the permanent wetland as low as $\sim 7.3 \mathrm{~cm}$, with exposed sediments along the wetland perimeter during the preceding month. There was a high rainfall event prior to $\mathrm{C} 1$ with $342 \mathrm{~mm}$ of rainfall recorded over the preceding 2 weeks and an additional $35 \mathrm{~mm}$ of rain occurring during $\mathrm{C} 1$ fieldwork (Fig. 2), thus raising the water column depth in the permanent wetland to $77.2 \mathrm{~cm}$ in less than 4 weeks. This $\mathrm{C} 1$ deployment was therefore categorised as the "post-dry-flooded" period, during which air temperatures ranged from 13.3 to $22.8^{\circ} \mathrm{C}$ and the average water column temperature in the permanent wetland was $20.4 \pm 0.5^{\circ} \mathrm{C}$. The second fieldwork campaign was conducted in September 2017 (C2) under cool-drying conditions, in which air temperatures ranged from as low as 3.4 to $34.9^{\circ} \mathrm{C}$ (Fig. 2), with cooler average water temperatures of $12.6 \pm 0.4{ }^{\circ} \mathrm{C}$ in the permanent wetland (Fig. 2). The depth of the permanent wetland at this time had dropped slightly to $\sim 33 \mathrm{~cm}$ (Fig. 2).

\subsection{Sediment core profiles and soil redox potentials}

Average concentrations from soil cores (Table 1, Fig. 3) were based upon the top $20 \mathrm{~cm}$ of the profile, in which the highest organic carbon concentrations were found. The $\mathrm{Fe}(\mathrm{III})_{\mathrm{HCl}}$ concentrations were greater than $\mathrm{Fe}(\mathrm{II})_{\mathrm{HCl}}$ at all three seasonal wetland sites; however, the permanent wetland showed an opposite trend with low concentrations of both $\mathrm{Fe}(\mathrm{III})\left(5.6 \pm 10.7 \mathrm{mmol} \mathrm{kg}^{-1}\right)$ and $\mathrm{SO}_{4}^{2-}(1.5 \pm$ $1.0 \mathrm{mmol} \mathrm{kg}^{-1}$ ) (Fig. 3, Table 1). The highest average concentrations of $\mathrm{Fe}(\mathrm{III})_{\mathrm{HCl}}$ were found at the Juncus-forest site $\left(204.0 \pm 51.6 \mathrm{mmol} \mathrm{kg}^{-1}\right)$ and the highest and similar concentrations of $\mathrm{SO}_{4}^{2-}$ were in Phragmites and Juncus-forest sediments $\left(45.4 \pm 41.0\right.$ and $43.3 \pm 16.7 \mathrm{mmol} \mathrm{kg}^{-1}$ ) (Fig. 3, Table 1). Net positive redox potential was found at all four sites during $\mathrm{C} 1$ (under post-dry-flooded conditions), indicating a lag time between recent flooding and the onset of reducing conditions. In contrast, a negative redox potential was found within the permanent wetland and Phragmites during $\mathrm{C} 2$, indicating reduced conditions under cool-drying conditions (Table 1). The TOC concentrations (\%) were highest in the upper profiles and similar across all sites (Fig. 3, Table 1), averaging $13.4 \pm 7.6 \%$.

\subsection{Permanent and seasonal wetland $\mathrm{CH}_{4}$ fluxes}

The vegetation time series revealed that diel variability of plant-mediated $\mathrm{CH}_{4}$ emissions occurred at most ecotypes, with the highest $\mathrm{CH}_{4}$ fluxes occurring during daytime around midday and the lowest $\mathrm{CH}_{4}$ fluxes during the night-time (Fig. 4, Table 1). The lowest $\mathrm{CH}_{4}$ fluxes were found in the Juncus-forest habitat with a net negative $\mathrm{CH}_{4}$ flux observed 


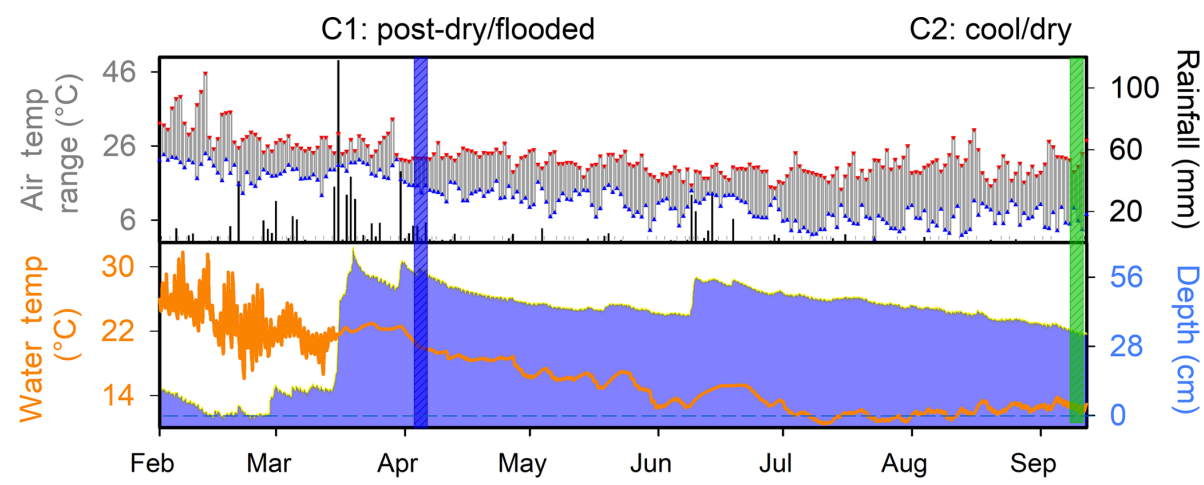

Figure 2. Hydrograph for 7 months in 2017 indicating daily rainfall, maximum-minimum air temperature, water temperature, and antecedent hydrology. Vertical coloured bands represent the two fieldwork campaigns.

Table 1. Summary of plant-mediated $\mathrm{CH}_{4}$ fluxes from the seasonal wetland time series and diel $\mathrm{CH}_{4}$ diffusive fluxes and ebullition from the permanent wetland during $\mathrm{C} 1$ (post-dry-flooded) and C2 (cool-drying). The corresponding sediment core data are average concentrations from 0 to $20 \mathrm{~cm}$ below ground level.

\begin{tabular}{|c|c|c|c|c|c|}
\hline $\mathrm{CH}_{4}$ flux $\left(\mathrm{mmol} \mathrm{m} \mathrm{m}^{-2} \mathrm{~d}^{-1}\right)$ & Ebullition & Diffusion & Juncus & Phragmites & Juncus-forest \\
\hline Sediment flux $-\mathrm{C} 1$ & & & 0.06 & 0.04 & 0.10 \\
\hline Daytime flux - C1 & & 0.57 & 1.79 & 2.64 & 0.13 \\
\hline Night-time flux - C1 & & 2.07 & 1.50 & 1.59 & 0.10 \\
\hline Daily average flux $-\mathrm{C} 1$ & 2.02 & 1.49 & 1.70 & 2.27 & 0.12 \\
\hline Sediment flux $-\mathrm{C} 2$ & & & 0.00 & 0.20 & 0.00 \\
\hline Daytime flux - C2 & & 11.72 & 0.06 & 0.94 & 0.13 \\
\hline Night-time flux - C2 & & 8.39 & 0.04 & 0.48 & 0.10 \\
\hline Daily average flux $-\mathrm{C} 2$ & 2.10 & 10.46 & 0.05 & 0.77 & -0.01 \\
\hline $\mathrm{FeHCl}(\mathrm{II})\left(\mathrm{mmol} \mathrm{kg}^{-1}\right)$ & & 202.3 & 11.6 & 15.4 & 1.5 \\
\hline $\mathrm{FeHCl}(\mathrm{III})\left(\mathrm{mmol} \mathrm{kg}^{-1}\right)$ & & 5.6 & 83.3 & 56.1 & 204.0 \\
\hline $\mathrm{SO}_{4}^{2-}\left(\mathrm{mmol} \mathrm{kg}^{-1}\right)$ & & 1.5 & 17.6 & 45.4 & 43.3 \\
\hline $\mathrm{Cl}: \mathrm{SO}_{4}^{2-}$ & & 14.8 & 8.4 & 13.9 & 7.4 \\
\hline $\operatorname{AVS}\left(\mu \mathrm{mol} \mathrm{g}{ }^{-1}\right)$ & & 18.5 & 0.7 & 0.9 & 0.3 \\
\hline TOC (\% C) & & 11.6 & 14.3 & 14.8 & 14.6 \\
\hline $\mathrm{C} 1-\operatorname{redox} \mathrm{Eh}(\mathrm{mV})$ & & 71.7 & 46.5 & 9.6 & 54.4 \\
\hline $\mathrm{C} 2$ - redox Eh $(\mathrm{mV})$ & & -216.3 & 11.9 & -89.3 & 424.5 \\
\hline
\end{tabular}

during $\mathrm{C} 2$ time series. The $\mathrm{CH}_{4}$ sediment fluxes measured amongst each vegetation time series were consistently much lower than the plant-mediated $\mathrm{CH}_{4}$ fluxes, indicating that the vegetation was indeed the main conduit for $\mathrm{CH}_{4}$ to the atmosphere (Fig. 4, Table 1). The $\mathrm{CH}_{4}$ fluxes were highly variable between the replicates at each site. Temperature and PAR followed similar diel trends to each other and had positive correlations with $\mathrm{CH}_{4}$ emissions (Fig. 4).

$\mathrm{CH}_{4}$ fluxes from the three vegetation types were significantly higher during $\mathrm{C} 1$ than during $\mathrm{C} 2(p<0.001)$. During $\mathrm{C} 1$, the $\mathrm{CH}_{4}$ fluxes from Juncus and Phragmites were not significantly different from each other but were both significantly higher $(p<0.001)$ than Juncus-forest; however, during $\mathrm{C} 2$ the $\mathrm{CH}_{4}$ fluxes of each seasonal wetland habitat were significantly different between all habitats $(p<0.05)$
(Fig. 5). The highest average $\mathrm{CH}_{4}$ fluxes in each of the vegetation types always occurred during the daytime but were not significantly different to night-time fluxes (Fig. 5, Table 1). Phragmites consistently emitted the highest $\mathrm{CH}_{4}$ fluxes $\left(2.27 \pm 1.42 \mathrm{mmol} \mathrm{m}^{-2} \mathrm{~d}^{-1}\right.$ during $\mathrm{C} 1$ and $0.77 \pm$ $0.46 \mathrm{mmol} \mathrm{m}^{-2} \mathrm{~d}^{-1}$ during $\mathrm{C} 2$ ). The Juncus-forest ecotype within the seasonal wetland consistently produced the lowest $\mathrm{CH}_{4}$ fluxes of all sites, with a negligible flux that was not significantly different from zero occurring during $\mathrm{C} 2$ $\left(-0.01 \pm 0.08 \mathrm{mmol} \mathrm{m}^{-2} \mathrm{~d}^{-1}\right)$.

The permanent wetland showed an inverse trend with 7 fold and significantly higher $(p<0.001)$ diffusive fluxes during the cool-drying $\mathrm{C} 2$ when lilies were present $(10.46 \pm$ $15.81 \mathrm{mmol} \mathrm{m}^{-2} \mathrm{~d}^{-1}$ ) compared to the post-dry-flooded $\mathrm{C} 1$ when no lilies were present $\left(1.49 \pm 2.75 \mathrm{mmol} \mathrm{m}^{-2} \mathrm{~d}^{-1}\right)$, 


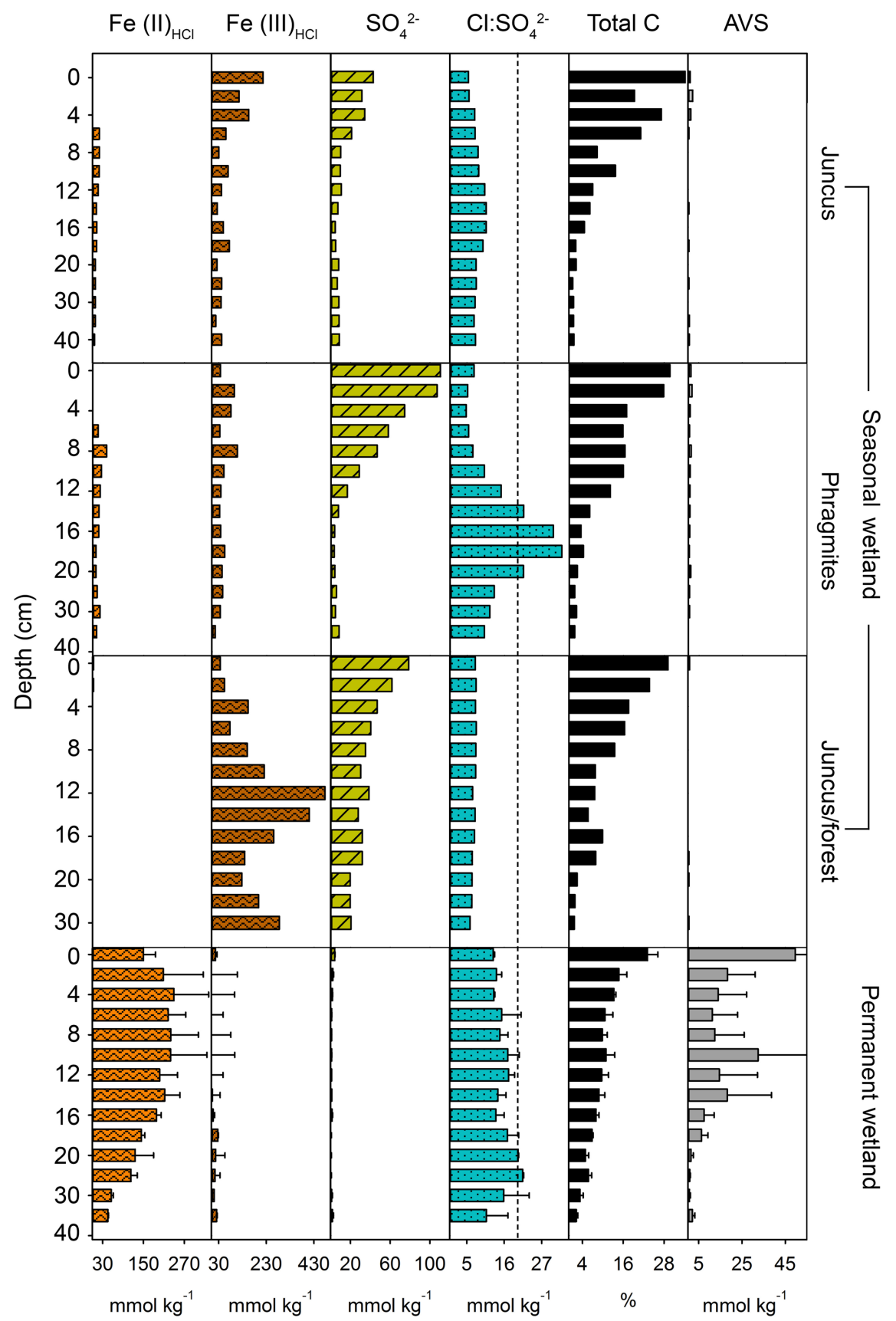

Figure 3. Soil profiles of the permanent and seasonal wetland sites indicating $\mathrm{Fe}(\mathrm{II})_{\mathrm{HCl}}, \mathrm{Fe}(\mathrm{III})_{\mathrm{HCl}}, \mathrm{SO}_{4}^{2-}, \mathrm{Cl}: \mathrm{SO}_{4}^{2-}$ (a proxy for depletion of marine-derived sulfate, where $>20$ is broadly indicative of $\mathrm{SO}_{4}^{2-}$ reduction and < 8 CASS pyrite oxidation; Mulvey, 1993), total C, and acid volatile sulfur (AVS). Note: the permanent wetland profiles are averages from two adjacent sites with error bars representing the standard deviation.

while the ebullition rates were similar during both campaigns (Fig. 5, Table 1). Overall, the diffusive fluxes of the permanent wetland were within the range of $\mathrm{CH}_{4}$ fluxes from the three seasonal wetland habitats but were significantly higher than Juncus-forest during both campaigns and Juncus during C2 (Fig. 5). Diel diffusive flux variability was not significant between daytime and night-time (Table 1, Fig. 5).

\subsection{Temperature and PAR}

Correlation plots for both temperature $\left({ }^{\circ} \mathrm{C}\right)$ and sunlight (PAR) versus $\mathrm{CH}_{4}$ emissions from the three vegetation ecotypes showed no distinct relationships with the exception of Phragmites during $\mathrm{C} 2$ for PAR $\left(r^{2}=0.18, p<0.01\right)$ and temperature $\left({ }^{\circ} \mathrm{C}\right)\left(r^{2}=0.35, p<0.001\right)$. No clearer trends 
C1 (post-dry/flooded)
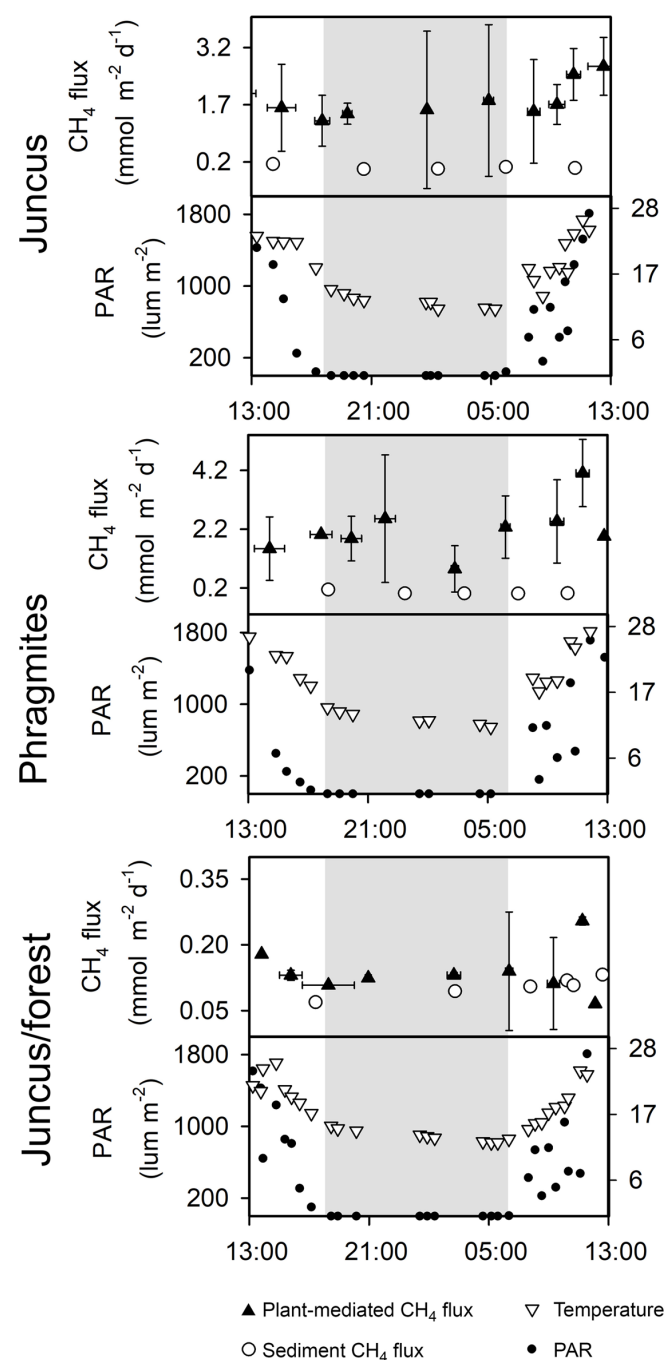

$\mathrm{C} 2$ (cool/drying)
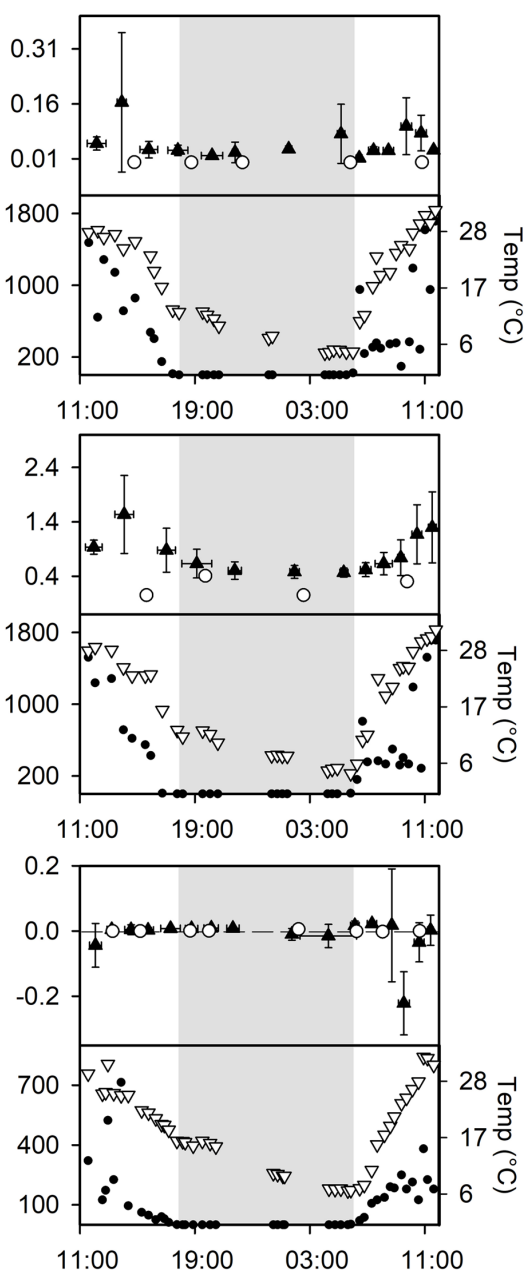

Figure 4. Simultaneous $24 \mathrm{~h}$ time series of vegetative $\mathrm{CH}_{4}$ fluxes from the seasonal wetland ecotypes at Cattai Wetlands during $\mathrm{C} 1$ (post-dry-flooded, April 2017) and C2 (cool-drying conditions, September 2017). The vertical error bars of the plant-mediated $\mathrm{CH}_{4}$ flux $\left(\mathrm{mmol} \mathrm{m} \mathrm{m}^{-2} \mathrm{~d}^{-1}\right)$ represent the standard deviation of the triplicate time series measurements taken from each site, and the horizontal bars represent the total aggregated time period represented by replicate chambers. The grey shading indicates night-time. Note: different $y$ axis scales for $\mathrm{CH}_{4}$ to highlight diel trends.

were observed by combining all site measurements or separating daytime fluxes and drivers from night-time fluxes and drivers.

\section{Discussion}

\subsection{Geochemistry of the CASS landscape}

Sediment profiles provide insights into the historical geochemical changes that have occurred across the CASS landscapes of the four Cattai Wetlands sites (Fig. 3). We base our results and discussion on the upper rhizosphere depth zone $(20 \mathrm{~cm})$ as this featured the highest organic carbon concen- trations and is therefore assumed to be an active area of carbon metabolism and $\mathrm{CH}_{4}$ production and consumption (Nedwell and Watson, 1995). If we assume that relatively uniform deposition of late Holocene materials occurred, the differences between present-day profiles are related to historical changes in hydrology and land use, topographic elevation, geochemical trajectories, and vegetative carbon inputs. For example, the permanent wetland shows distinct differences to the adjacent seasonal wetland sites, with divergent geochemical signatures of both iron and sulfate that reflect sustained inundation (Table 1, Fig 5). The permanent wetland had significantly lower $\mathrm{Fe}(\mathrm{III})(p<0.001)$ and $11-$ to 30 -fold lower $\mathrm{SO}_{4}^{2-}$ concentrations within the upper soil pro- 

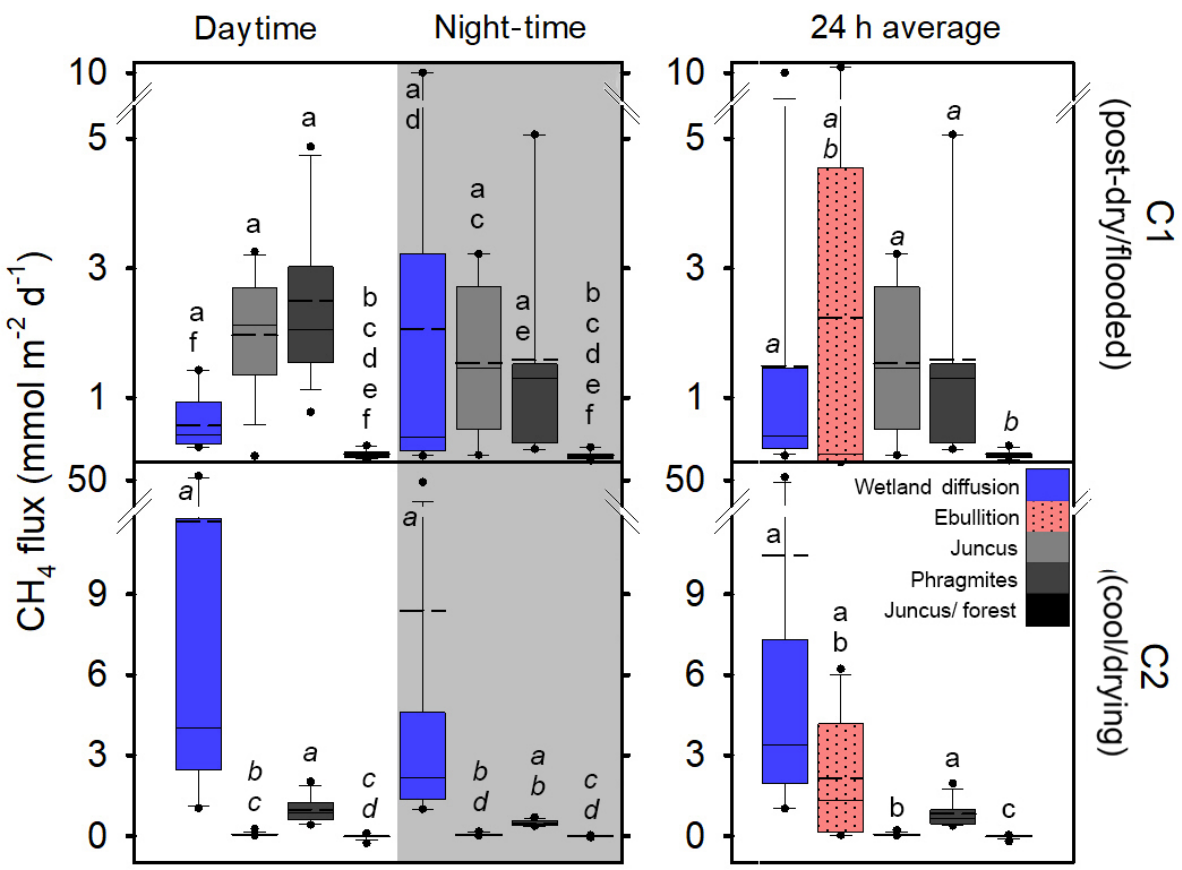

Figure 5. Fluxes of $\mathrm{CH}_{4}$ from diel sampling and ebullition over two campaigns from the permanent wetland and adjacent $24 \mathrm{~h}$ time series of the seasonal wetland vegetation types. Note: diffusive fluxes during C2 include chambers featuring lilies, dashed line represents the average, solid line represents the median, and dots represent the 5 th and 95 th percentiles. Letters show groups that did not differ significantly $(p>0.05)$ using ANOVA on ranks and Dunn's pairwise comparisons within each campaign.

file compared to the seasonal wetland. The ratio of $\mathrm{Fe}(\mathrm{III})_{\mathrm{HCl}}$ to $\mathrm{Fe}(\mathrm{II})_{\mathrm{HCl}}$ from the flooded soils of the permanent wetland was 0.03 , indicating the sediments were almost completely depleted of $\mathrm{Fe}(\mathrm{III})$. Under reducing conditions in which there is low $\mathrm{SO}_{4}^{2-}$ and little to no $\mathrm{Fe}$ (III) to competitively exclude methanogenesis, $\mathrm{CH}_{4}$ production becomes more favourable. Indeed, $\mathrm{CH}_{4}$ production was on average the highest from the permanent wetland, especially when considering the duel $\mathrm{CH}_{4}$ pathways of ebullition and air-water diffusion (Table 1).

In addition to sulfate reduction, some depletion of the sulfur pool from the permanent wetland may have occurred due to drainage exports of sulfuric acid $\left(\mathrm{H}_{2} \mathrm{SO}_{4}\right)$ discharging from the CASS landscape throughout the last century. Alternatively, reducing conditions induced by re-flooding freshwater wetlands is known to encourage the re-formation of AVS and pyrite $\left(\mathrm{FeS}_{2}\right)$ and produce alkalinity, thereby attenuating acid production and discharge (Burton et al., 2007; Johnston et al., 2012, 2014) and reducing the total $\mathrm{SO}_{4}^{2-}$ pool of CASS landscapes. While the AVS concentrations found within the permanent wetland (up to $18.5 \mu \mathrm{mol} \mathrm{g}^{-1}$ ) were a result of sulfate reduction induced by CASS wetland restoration, they nonetheless represent a relatively volatile form of sulfur, which is at risk of rapid oxidation during drought periods (Johnston et al., 2014; Karimian et al., 2017). The AVS concentrations of the permanent wetland sites were more than 20-fold higher than the three adjacent seasonal wetland sites and represent a potentially volatile by-product and con- sequence of re-flooding CASS soil landscapes, in addition to leading to increases in $\mathrm{CH}_{4}$ emissions (Table 1).

The soil profile from the seasonal wetland Juncus-forest habitat featured abundant $\mathrm{Fe}(\mathrm{III})_{\mathrm{HCl}}$ (with an $\mathrm{Fe}(\mathrm{III})_{\mathrm{HCl}}$ to $\mathrm{Fe}(\mathrm{II})_{\mathrm{HCl}}$ ratio of 136) and also $\mathrm{SO}_{4}^{2-}$. This was associated with the lowest fluxes of $\mathrm{CH}_{4}$ for both sampling periods (Fig. 3, Table 1). Relatively low $\mathrm{CH}_{4}$ fluxes from Juncus-forest are likely due to the more oxidising conditions present at this site and the surfeit of thermodynamically favourable terminal electron acceptors (i.e. Fe(III) and $\mathrm{SO}_{4}^{2-}$ ), which would competitively exclude organic matter degradation by methanogenic Archaea (Postma and Jakobsen, 1996). At the other seasonal wetland sites, the average $\mathrm{Fe}(\mathrm{III})$ and $\mathrm{SO}_{4}^{2-}$ concentrations were intermediate (i.e. lower than Juncus-forest, but higher than the permanent wetland), although in the upper profile the Phragmites had more $\mathrm{SO}_{4}^{2-}$, while Juncus had more Fe(III) (Fig. 3, Table 1). $\mathrm{CH}_{4}$ flux values from these sites were also intermediate (Table 1). Sediment profiles from both Juncus and Phragmites indicated a degree of Fe reduction based on the ratios of $\mathrm{Fe}(\mathrm{III})$ : $\mathrm{Fe}(\mathrm{II})$, which were 7.2 and 3.6, respectively. The redox potentials from Phragmites during both the $\mathrm{C} 1$ and $\mathrm{C} 2$ campaigns (9.6 and $-89.0 \mathrm{mV}$, respectively) were consistently lower than Juncus during the $\mathrm{C} 1$ and $\mathrm{C} 2$ campaigns (46.5 and $12.0 \mathrm{mV}$, respectively), which is consistent with the more reducing conditions encouraging $\mathrm{CH}_{4}$ production in the Phragmites habitat. Further, as iron reduction yields more free energy 
than $\mathrm{SO}_{4}^{2-}$ reduction (Burdige, 2012), then Fe reduction at the Juncus site may outcompete $\mathrm{CH}_{4}$ production ahead of $\mathrm{SO}_{4}^{2-}$ reduction in Phragmites, which may help explain some of the differences in $\mathrm{CH}_{4}$ production between the two sites. The positive significant trends between $\mathrm{Fe}(\mathrm{II}), \mathrm{AVS}$, and the $\mathrm{Cl}$ : $\mathrm{SO}_{4}^{2-}$ ratios with $\mathrm{CH}_{4}$ flux rates $\left(r_{\mathrm{s}}=0.88, p<0.01\right)$ further support our hypothesis that reducing conditions and a smaller pool of sediment $\mathrm{Fe}$ (III) and $\mathrm{SO}_{4}^{2-}$ facilitate higher $\mathrm{CH}_{4}$ production rates (Fig. 7). Alternatively, the negative trends observed between soil redox potentials, $\mathrm{SO}_{4}^{2-}, \mathrm{Fe}(\mathrm{III})$, and $\mathrm{CH}_{4}$ fluxes affirm that the abundance of thermodynamically favourable terminal electron acceptors plays a role in attenuating $\mathrm{CH}_{4}$ production at each site.

\subsection{Plant-mediated $\mathrm{CH}_{4}$ fluxes from the seasonal wetland}

Plant-mediated $\mathrm{CH}_{4}$ fluxes were significantly higher $(p<0.001)$ during $\mathrm{C} 1$ under post-dry-flooded conditions with $20-30 \mathrm{~cm}$ of standing waters in the seasonal wetland (Table 1). While waterlogged conditions are an obvious driver of higher $\mathrm{CH}_{4}$ production rates from saturated sediments in addition to the geochemical differences (previously discussed), other drivers which may explain these trends include differences in diel variability in temperature, PAR, and plant physiology, which may influence $\mathrm{CH}_{4}$ gas transport pathways.

In vegetated seasonal wetlands, plant-mediated gas transport is recognised as a dominant pathway for $\mathrm{CH}_{4}$ emission to the atmosphere and accounts for up to $90 \%$ of total wetland fluxes (Whiting and Chanton, 1992; Sorrell and Boon, 1994). For plant survival in near-permanent inundation environments, oxygen transport occurs via the aerenchyma downwards to the rhizome. This increases plant performance by mitigating (i.e. oxidising) the accumulation of phytotoxins such as sulfides and reducing metal ions around the roots (Penhale and Wetzel, 1983; Armstrong and Armstrong, 1990; Armstrong et al., 2006). As oxygen transfer to the rhizosphere occurs, an exchange of sedimentary $\mathrm{CH}_{4}$ can be efficiently transported from the rhizosphere to atmosphere, bypassing sedimentary oxidative processes along the way. This process in plants can be either convective (i.e. pressurised) or via passive diffusive gas flow, both of which are adaptive traits of many wetland species (Armstrong and Armstrong, 1991; Konnerup et al., 2011).

During both campaigns the highest $\mathrm{CH}_{4}$ fluxes from seasonal wetland vegetation were emitted from Phragmites and always occurred during daylight (Table 1, Fig. 8). In Phragmites australis, the presence of pressurised lacunar leaf culms drive a mass flow of oxygen to the rhizome and back to the atmosphere via older (non-pressurised) efflux culms (Sorrell and Boon, 1994; Henneberg et al., 2012). This process has been widely studied in wetlands featuring Phragmites australis, as it is one of the most productive and widespread flowering wetland species (Tucker, 1990; Clevering and Liss- ner, 1999; Brix et al., 2001; Chanton et al., 2002). Milberg et al. (2017) found no apparent diel patterns of $\mathrm{CH}_{4}$ fluxes from Phragmites australis during seven campaigns within the Swedish growing season. In a mid-latitude prairie wetland, Kim et al. (1998) showed that $\mathrm{CH}_{4}$ emissions peaked around midday and that daytime emissions were about 3fold higher than night-time emissions, positively correlating with temperature and PAR. These were similar to our findings with the highest $\mathrm{CH}_{4}$ fluxes of each time series occurring near midday local time $\left(4.88 \mathrm{mmol} \mathrm{m}^{-2} \mathrm{~d}^{-1}\right.$ at $10: 50 \mathrm{LT}$ during $\mathrm{C} 1$ and $2.06 \mathrm{mmol} \mathrm{m}^{-2} \mathrm{~d}^{-1}$ at $12: 15 \mathrm{LT}$ during $\mathrm{C} 2$ ) (Fig. 4). We also found a positive significant relationship between $\mathrm{CH}_{4}$ flux and both temperature and PAR during $\mathrm{C} 2$ (Fig. 6). The often high diel variability in $\mathrm{CH}_{4}$ fluxes from Phragmites australis occurs as convective gas transport increases rhizospheric oxygen and $\mathrm{CH}_{4}$ exchange via living culms during the daytime, whereas molecular diffusion during the night-time facilitates a more passive and lower $\mathrm{CH}_{4}$ flux pathway through dead culms (Armstrong and Armstrong, 1991; Chanton et al., 2002).

One possible reason $\mathrm{CH}_{4}$ fluxes were lower from Juncus than Phragmites despite their close geographical location may be due to the passive gas diffusion mechanism utilised by Juncus spp. (Henneberg et al., 2012). Unlike the pressurised conductive gas flow mechanisms of Phragmites, many wetland rush species (such as Juncus spp.) employ passive diffusive gas flow to survive within waterlogging environments (Brix et al., 1992; Konnerup et al., 2011). Despite diffusion being a less efficient gas transport mechanism (Konnerup et al., 2011), plant-mediated $\mathrm{CH}_{4}$ diffusion is recognised as the dominant pathway for $\mathrm{CH}_{4}$ emissions from many seasonal wetland species. During $\mathrm{C} 1$ and $\mathrm{C} 2$, daytime fluxes (diffusive) from Juncus were only $19 \%$ and $33 \%$ higher than night-time fluxes (diffusive). In comparison, from Phragmites these day-to-night ratios were almost triple this (67\% and $94 \%$ higher) during the same periods. This may potentially be due to the more efficient daytime conductive gas transfer pathway of $\mathrm{CH}_{4}$ through Phragmites australis compared to the more passive diffusive $\mathrm{CH}_{4}$ gas transfer pathway of Juncus kraussii and/or the effectiveness of these different species in altering sedimentary redox conditions. This suggests that non-pressurised pathways may result in lower net rhizosphere-atmosphere gas exchange of $\mathrm{CH}_{4}$ from seasonal wetland vegetation. Alternatively, root depth and root density differ between these two species (De La Cruz and Hackney, 1977; Moore et al., 2012), which may further influence redox dynamics in the rhizosphere and the potential extent of net gas exchange.

The Juncus-forest habitat emitted significantly lower fluxes of $\mathrm{CH}_{4}$ during both time series campaigns and was a net sink for $\mathrm{CH}_{4}$ during $\mathrm{C} 2$ (Table 1, Fig. 8). Although wetland trees have recently been shown to contribute significantly to $\mathrm{CH}_{4}$ fluxes from flooded environments (Pangala et al., 2017), we could not quantify or constrain the role of trees as a conduit of methane to the atmosphere at this 

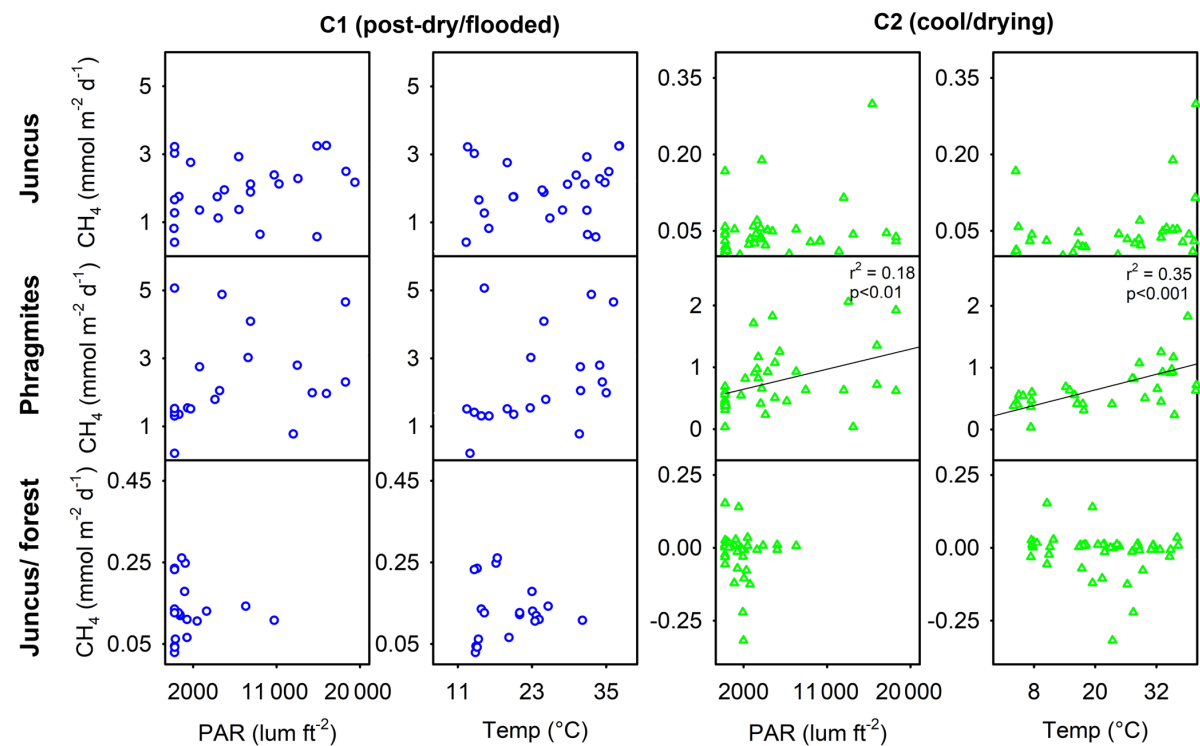

Figure 6. Correlations of $\mathrm{CH}_{4}$ with temperature $\left({ }^{\circ} \mathrm{C}\right)$ and photosynthetically active radiation (PAR) (lum $\mathrm{ft}^{-2}$ ) for the three wetland vegetation sites of Cattai Wetlands during two field campaigns.
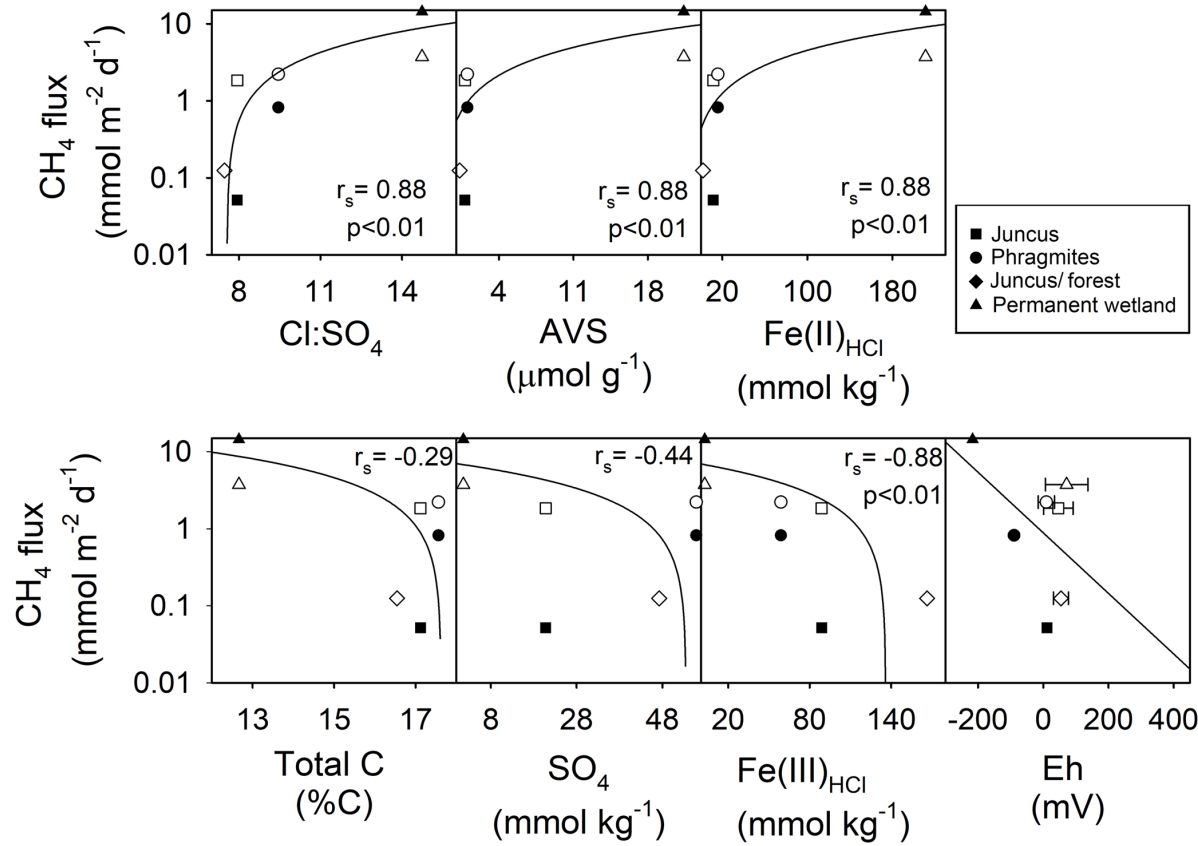

Figure 7. Regression analysis of average daily $\mathrm{CH}_{4}$ fluxes $\left(\mathrm{mmol} \mathrm{m}^{-2} \mathrm{~d}^{-1}\right)$ vs. subsoil parameters of $0-20 \mathrm{~cm}$ core depth (i.e. $\mathrm{CH}_{4}$ "active" zone). Note: $\log$ scale $y$ axis of $\mathrm{CH}_{4}$ fluxes from the four wetland ecotypes over two campaigns. Note: the $r_{s}$ values calculated using Spearman rho are for $\mathrm{C} 1$ (black shapes) and C2 (white shapes).

site. Regardless, there were clearly lower $\mathrm{CH}_{4}$ fluxes through the Juncus kraussii at the Juncus-forest habitat compared to the Juncus-only habitat. As the species at ground level were identical, these differences are not related to vegetative gas transport mechanisms or organic carbon content (Table 1). Shading by the overhanging trees may inhibit daytime diffusive $\mathrm{CH}_{4}$ gas transport through the Juncus-forest habitat, presumably due to lower rates of photosynthesis; however, PAR was only lower during C2 (Fig. 7) and therefore does not appear to explain the $\mathrm{CH}_{4}$ flux differences observed during $\mathrm{C} 1$. The differences are therefore likely explained by the higher positive redox potentials (Table 1) that may be partially attributable to rhizome aeration by the nearby trees and more abundant thermodynamically favourable terminal elec- 


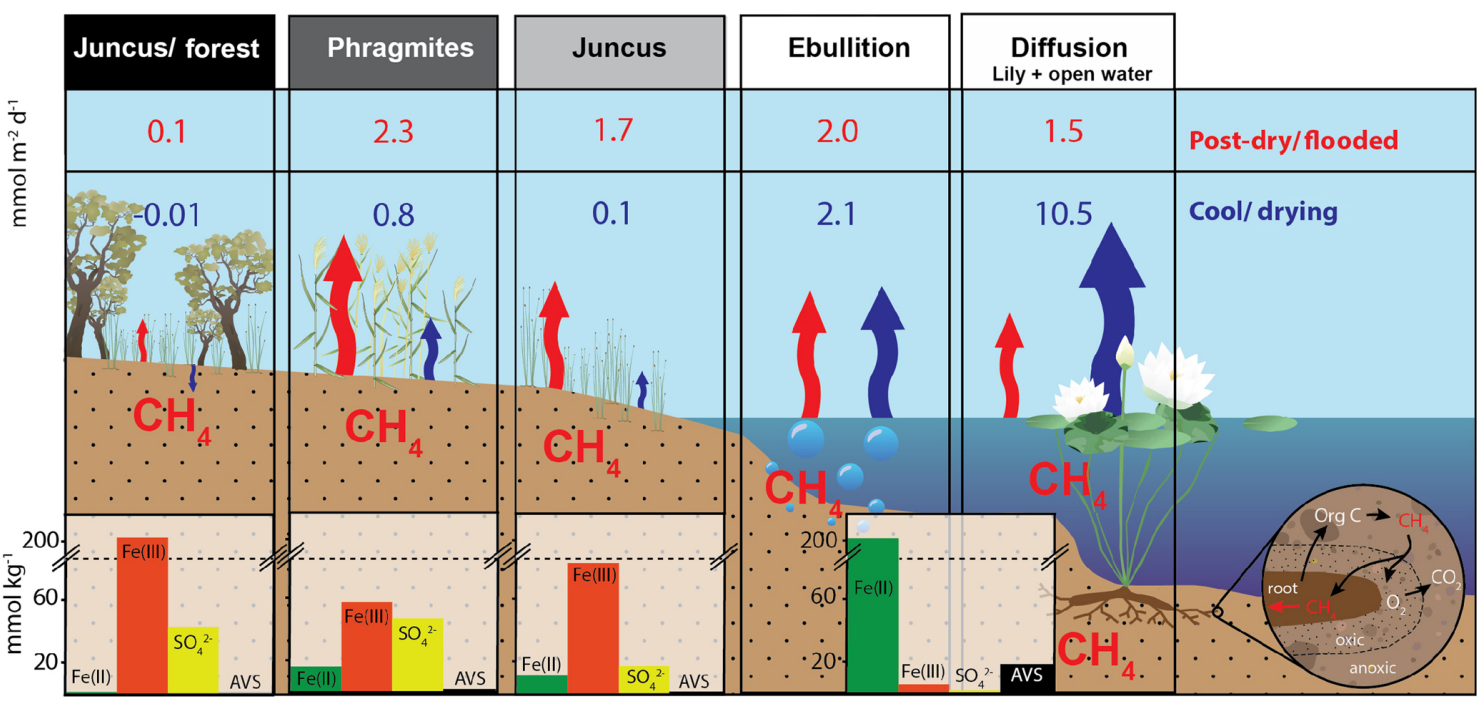

Figure 8. Conceptual model summarising the terrestrial and aquatic $\mathrm{CH}_{4}$ fluxes $\left(\mathrm{mmol} \mathrm{m}^{-2} \mathrm{~d}^{-1}\right)$ and sediment core profile parameters $(\mathrm{mmol} \mathrm{kg}-1)$ of the permanent and seasonal wetlands during $\mathrm{C} 1$ (post-dry-flooded conditions) and C2 (cool-drying conditions) of Cattai Wetlands. Conceptual diagram rhizome process insert adapted from Conrad (1993). Note: dashed line highlights $y$ axis break.

tron acceptors (i.e. $\mathrm{Fe}(\mathrm{III})$ and $\mathrm{SO}_{4}^{2-}$ ) (Fig. 3), all of which can inhibit methane production within the sediments (Burdige, 2012).

\subsection{Permanent wetland $\mathrm{CH}_{4}$ fluxes}

Diffusive $\mathrm{CH}_{4}$ fluxes from the permanent wetland varied considerably between campaigns; however, ebullition fluxes were similar (Table 1, Fig. 8). The highest $\mathrm{CH}_{4}$ fluxes for both ebullition and diffusion $\left(2.1\right.$ and $10.5 \mathrm{mmol} \mathrm{m}^{-2} \mathrm{~d}^{-1}$, respectively) occurred during $\mathrm{C} 2$ despite cooler conditions (Figs. 2 and 8). This, however, was the opposite trend to the seasonal wetland $\mathrm{CH}_{4}$ fluxes (Table 1, Fig. 8). One reason may be the antecedent hydrological conditions before C1 (Fig. 2). Jeffrey et al. (2019) reported that a water level drawdown of the permanent wetland after a hot and drying summer period exposed some of the permanent wetland sediments to oxidative conditions. This may have oxidised a portion of the labile sedimentary carbon pool prior to $\mathrm{C} 1$ sampling of the permanent wetland, therefore reducing the total $\mathrm{CH}_{4}$ pool observed during $\mathrm{C} 1$ sampling. A lag time (ranging from weeks to months) for recovery of the $\mathrm{CH}_{4}$ pool post-drought has been observed in other systems (Boon et al., 1997) and also during lab-based experiments (Freeman et al., 1992; Knorr et al., 2008). Further, during C2 the return of macrophyte species Nymphaea capensis most likely enhanced $\mathrm{CH}_{4}$ gas transport from the rhizosphere to the floating chambers, as discussed in detail in Jeffrey et al. (2019). Therefore, this combination of drivers most likely explains the higher $\mathrm{CH}_{4}$ fluxes during $\mathrm{C} 2$ when the system (and lilies) had sufficient time to recover, despite lower water column temperatures that would normally reduce microbial metabolism rates. This hypothesis is also supported by the shift of net positive redox potential of the permanent wetland during $\mathrm{C} 1(71.7 \pm 65 \mathrm{mV})$ to a strong negative redox potential during $\mathrm{C} 2(-216 \pm 42 \mathrm{mV})$, indicating that there was a time lag for reducing conditions to recover within the permanent wetland for $\mathrm{C} 2$. Further, although aquatic vegetation can facilitate root zone aeration, therefore increasing sedimentary redox potentials, as no aquatic vegetation was present in the permanent wetland during $\mathrm{C} 1$, this suggests that water level drawdown was the main driver of the observed redox conditions. This highlights the critical role of antecedent hydrological conditions and how dynamic weather oscillations of drought and floods (a common occurrence of many Australian wetland systems) strongly influence redox potentials, soil geochemistry, and ultimately $\mathrm{CH}_{4}$ fluxes.

\subsection{Implications and conclusions}

Within the global wetland $\mathrm{CH}_{4}$ budget, both subtropical systems and Southern Hemisphere systems are poorly represented (Bartlett and Harriss, 1993; Bastviken et al., 2011) (Fig. 9). Further, the fluxes from seasonal wetlands are poorly constrained (Pfeifer-Meister et al., 2018) due to their intermittent nature and variability of intra-seasonal areal extent, which may compound the fact that natural wetlands have the largest uncertainty of the global methane budget (Kirschke et al., 2013; Saunois et al., 2016). Although the temporal resolution of our study cannot be upscaled to realistic annual estimates, our high-resolution sampling strategy provided insights into daily $\mathrm{CH}_{4}$ flux rates, revealing distinct differences between different vegetation types across the terrestrial-aquatic wetland boundary. Our $\mathrm{CH}_{4}$ emissions rates were at the low end of the scale of measurements made in Southern Hemisphere subtropical systems but within the 


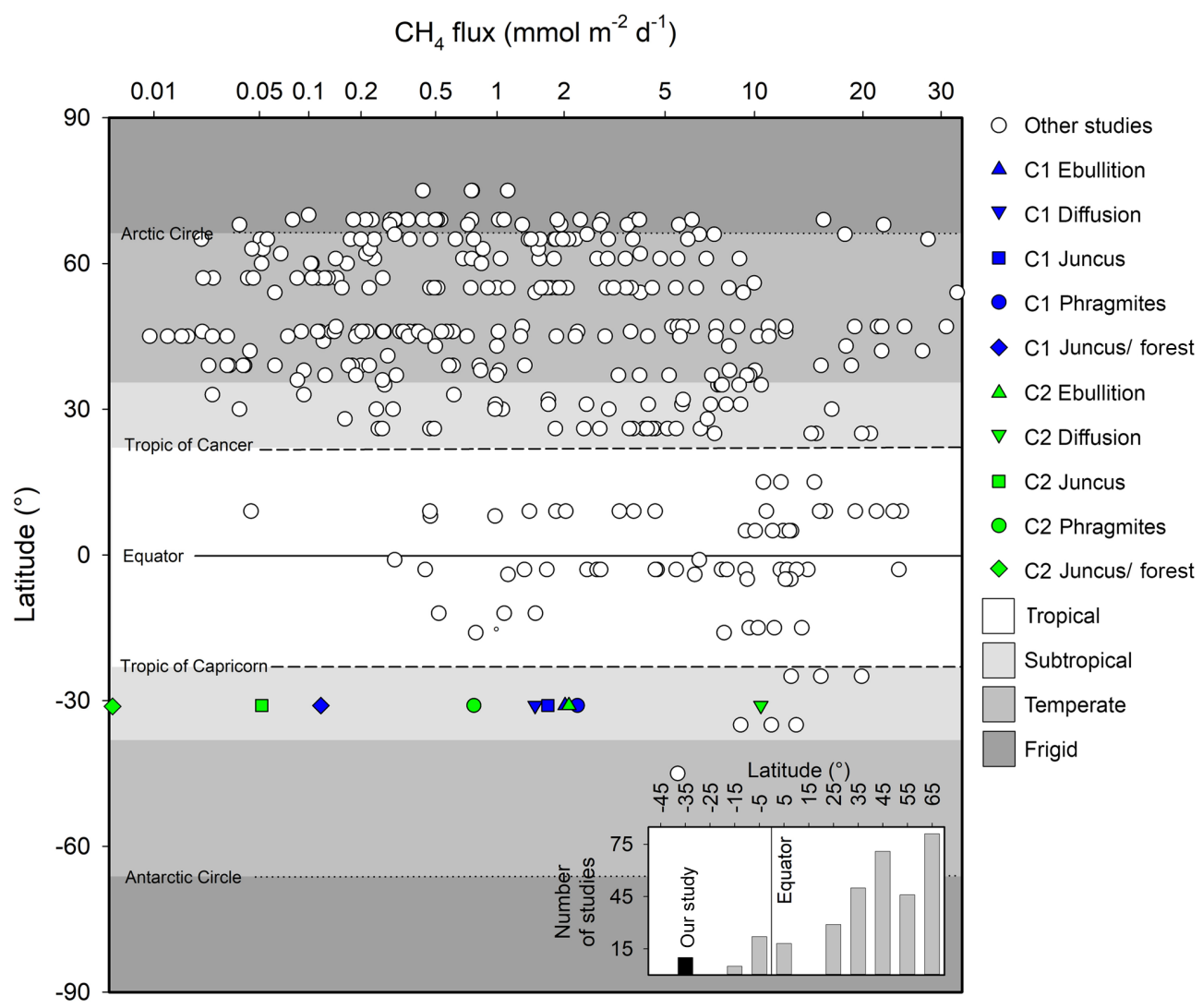

Figure 9. Summary of major $\mathrm{CH}_{4}$ wetland reviews by Bartlett and Harriss (1993) and Bastviken et al. (2011), as well as modelled fluxes by Cao et al. (1998) adapted from Jeffrey et al. (2019), highlighting latitudinal trends and bias from a variety of wetland systems. Inset figure highlights the number of studies in these reviews by latitudinal increments of $10^{\circ}$ poleward of the Equator. Note: $x$ axis scaled to highlight subtle differences between studies.

range of Northern Hemisphere subtropical systems of similar latitudes (Fig. 9).

Although remediating degraded wetlands through reflooding is a common technique to improve biodiversity, increase $\mathrm{C}$ sequestration, and improve downstream water quality issues (Johnston et al., 2004, 2014), our results propose a nuanced dilemma for land use managers, as wetland remediation can potentially have net positive radiative forcing effects on the Earth's climate due to high rates of $\mathrm{CH}_{4}$ production (Petrescu et al., 2015). This has also been shown to be particularly high during early remediation periods (Hemes et al., 2018). Our results suggest that seasonal wetlands emit less $\mathrm{CH}_{4}$ on an areal basis than permanent wetlands, yet carbon accumulation in these soils may be lower (Brown et al., 2019). Longer-term studies over annual cycles encompassing seasonal drivers and $\mathrm{CH}_{4}$ fluxes would further test this hypothesis of the different drivers between seasonal and permanent wetland systems.

Our results also suggest that selective hydrological restoration of wetlands featuring sediments with abundant thermodynamically favourable terminal electron acceptors (i.e. $\mathrm{Fe}(\mathrm{III})$ or $\mathrm{SO}_{4}^{2-}$ ) may be a (partial) biogeochemical solution (also suggested by Hemes et al., 2018) to both remediate degraded sites whilst simultaneously mitigating some $\mathrm{CH}_{4}$ emissions. When $\mathrm{Fe}(\mathrm{III})$ and $\mathrm{SO}_{4}^{2-}$ are abundant in anaerobic environments they provide preferential terminal electron acceptors for microbial metabolism and thus limit methanogenesis via competitive exclusion (Achtnich et al., 1995). However, high rates of sulfate reduction coupled with Fe reduction can also lead to the accumulation of metal sulfide minerals, e.g. pyrite and AVS (Johnston et al., 2014). Under permanently saturated and low oxygen conditions, metal sulfides will steadily accumulate and remain relatively benign. However, if the saturated state of remediated sites cannot be maintained, AVS may react with oxygen, resulting in the undesirable production of acidity and low $\mathrm{pH}$ conditions. Therefore, the remediation of wetlands for carbon storage should involve careful site selection to both limit $\mathrm{CH}_{4}$ production and to avoid redox-related geochemical by-products with detrimental environmental effects.

This study has highlighted how sediment geochemistry is intimately related to $\mathrm{CH}_{4}$ production and consumption. While high sulfate and $\mathrm{Fe}(\mathrm{III})$ favour lower $\mathrm{CH}_{4}$ production, sites featuring more reducing conditions and depleted sul- 
fate and $\mathrm{Fe}$ (III) favour the highest $\mathrm{CH}_{4}$ fluxes. Results reveal distinct differences between the areal $\mathrm{CH}_{4}$ fluxes of four different ecotypes located within a remediated subtropical Australian wetland and indicate high variability between campaigns. By combining novel and well-established techniques we delineated several $\mathrm{CH}_{4}$ pathways of both seasonal and permanent wetland sources (ebullition, diffusion, and plantmediated pathways) and linked these to hydrological drivers. This provided evidence that soil geochemistry is an important factor to consider for wetland remediation in the context of $\mathrm{CH}_{4}$ production and mitigation strategies. The $\mathrm{CH}_{4}$ emissions results were comparable to other wetlands of similar latitudes and contribute important data for both the understudied Southern Hemisphere wetlands and seasonal subtropical wetland ecotypes.

Data availability. Data used for the composition of this paper can be obtained from https://data.mendeley.com/datasets/st4vyjc73f/ 1 (last access: 24 April 2019) (Jeffrey, 2019).

Author contributions. LCJ, DRT, SGJ, and DTM conceived the study. LCJ wrote the first draft. LCJ, DRT, SGJ, and KM conducted the fieldwork. LCJ, DRT, SGJ, DTM, ADLS, and KM reviewed and edited the paper.

Competing interests. The authors declare that they have no conflict of interest.

Acknowledgements. We would like to thank to Roz Hagan, Bob McDonnell, and Zach Ford for assistance in the field. We also thank Roz Hagan for processing the sediment cores, Isaac Santos and Ceylena Holloway for technical support, and the Mid-Coast Council for assistance. Luke C. Jeffrey acknowledges postgraduate support from CSIRO. This work was supported by funding from the Australian Research Council (LP160100061). DRT and DTM acknowledge support from the Australian Research Council that partially funds their salaries (DE180100535 and DE150100581, respectively). Graphic components used in the conceptual model are courtesy of the Integration and Application Network, University of Maryland Centre for Environmental Science (http://ian.umces.edu/ symbols/, last access: June 2018).

Review statement. This paper was edited by Alexey V. Eliseev and reviewed by two anonymous referees.

\section{References}

Achtnich, C., Bak, F., and Conrad, R.: Competition for electron donors among nitrate reducers, ferric iron reducers, sulfate reducers, and methanogens in anoxic paddy soil, Biol. Fert. Soils, 19, 65-72, 1995.
ANCA: Issues paper for the Wise use Workshop, 4-6 December, Wetlands and migratory Wildlife Unit of the Australian Nature Conservation Agency, Canberra, Australia, 42 pp., 1995.

á Norði, K. and Thamdrup, B.: Nitrate-dependent anaerobic methane oxidation in a freshwater sediment, Geochim. Cosmochim. Ac., 132, 141-150, 2014.

Armentano, T. and Menges, E.: Patterns of change in the carbon balance of organic soil-wetlands of the temperate zone, J. Ecol., 755-774, 1986.

Armstrong, J. and Armstrong, W.: Light-enhanced convective throughflow increases oxygenation in rhizomes and rhizosphere of Phragmites australis (Cav.) Trin. ex Steud, New Phytol., 114, 121-128, 1990.

Armstrong, J. and Armstrong, W.: A convective through-flow of gases in Phragmites australis (Cav.) Trin. ex Steud, Aquat. Bot., 39, 75-88, 1991.

Armstrong, J., Jones, R., and Armstrong, W.: Rhizome phyllosphere oxygenation in Phragmites and other species in relation to redox potential, convective gas flow, submergence and aeration pathways, New Phytol., 172, 719-731, 2006.

Bartlett, K. B. and Harriss, R. C.: Review and assessment of methane emissions from wetlands, Chemosphere, 26, 261-320, 1993.

Bastviken, D., Tranvik, L. J., Downing, J. A., Crill, P. M., and Enrich-Prast, A.: Freshwater methane emissions offset the continental carbon sink, Science, 331, 50, 2011.

Bianchi, T. S.: Biogeochemistry of estuaries, Oxford University Press, New York, USA, 2007.

BOM: Taree Daily Weather Observations, available at: http://www. bom.gov.au/products/IDN60801/IDN60801.95784.shtml, last access: 12 April 2018.

Boman, A., Åström, M., and Fröjdö, S.: Sulfur dynamics in boreal acid sulfate soils rich in metastable iron sulfide - the role of artificial drainage, Chem. Geol., 255, 68-77, 2008.

Boon, P. I., Mitchell, A., and Lee, K.: Effects of wetting and drying on methane emissions from ephemeral floodplain wetlands in south-eastern Australia, Hydrobiologia, 357, 73-87, 1997.

Bridgham, S. D., Moore, T. R., Richardson, C. J., and Roulet, N. T.: Errors in greenhouse forcing and soil carbon sequestration estimates in freshwater wetlands: a comment on Mitsch et al. (2013), Landscape Ecol., 29, 1481-1485, 2014.

Brix, H., Sorrell, B. K., and Orr, P. T.: Internal pressurization and convective gas flow in some emergent freshwater macrophytes, Limnol. Oceanogr., 37, 1420-1433, 1992.

Brix, H., Sorrell, B. K., and Lorenzen, B.: Are Phragmitesdominated wetlands a net source or net sink of greenhouse gases?, Aquat. Bot., 69, 313-324, 2001.

Brown, D. R., Johnston, S. G., Santos, I. R., Holloway, C. J., and Sanders, C. J.: Significant organic carbon accumulation in two coastal acid sulfate soil wetlands, Geophys. Res. Lett., 46, 32453251, https://doi.org/10.1029/2019g1082076, 2019.

Burdige, D.: Estuarine and coastal sediments-coupled biogeochemical cycling, Treatise on Estuarine and Coastal Science, 5, 279316, 2012.

Burton, E., Bush, R. T., Johnston, S. G., Sullivan, L. A., and Keene, A. F.: Sulfur biogeochemical cycling and novel Fe-S mineralization pathways in a tidally re-flooded wetland, Geochim. Cosmochim. Ac., 75, 3434-3451, 2011. 
Burton, E. D., Bush, R. T., and Sullivan, L. A.: Elemental sulfur in drain sediments associated with acid sulfate soils, Appl. Geochem., 21, 1240-1247, 2006.

Burton, E. D., Bush, R. T., Sullivan, L. A., and Mitchell, D. R. G.: Reductive transformation of iron and sulfur in schwertmannite-rich accumulations associated with acidified coastal lowlands, Geochim. Cosmochim. Ac., 71, 4456-4473, https://doi.org/10.1016/j.gca.2007.07.007, 2007.

Cao, M., Gregson, K., and Marshall, S.: Global methane emission from wetlands and its sensitivity to climate change, Atmos. Environ., 32, 3293-3299, 1998.

Chanton, J. P., Arkebauer, T. J., Harden, H. S., and Verma, S. B.: Diel variation in lacunal $\mathrm{CH}_{4}$ and $\mathrm{CO}_{2}$ concentration and $\delta{ }^{13} \mathrm{C}$ in Phragmites australis, Biogeochemistry, 59, 287-301, 2002.

Claff, S. R., Sullivan, L. A., Burton, E. D., and Bush, R. T.: A sequential extraction procedure for acid sulfate soils: partitioning of iron, Geoderma, 155, 224-230, 2010.

Clevering, O. A. and Lissner, J.: Taxonomy, chromosome numbers, clonal diversity and population dynamics of Phragmites australis, Aquat. Bot., 64, 185-208, 1999.

Conrad, R.: Mechanisms controlling methane emission from wetland rice fields, in: Biogeochemistry of Global Change, Springer, Boston, MA, USA, 317-335, 1993.

Costanza, R., de Groot, R., Sutton, P., van der Ploeg, S., Anderson, S. J., Kubiszewski, I., Farber, S., and Turner, R. K.: Changes in the global value of ecosystem services, Global Environ. Chang., 26, 152-158, 2014.

De La Cruz, A. A. and Hackney, C. T.: Enegry Value, Elemental Composition, and Productivity of Belowground Biomass of a Juncus Tidal Marsh, Ecology, 58, 1165-1170, 1977.

Deverel, S. J., Ingrum, T., and Leighton, D.: Present-day oxidative subsidence of organic soils and mitigation in the SacramentoSan Joaquin Delta, California, USA, Hydrogeol. J., 24, 569-586, 2016.

Finlayson, C. M. and Rea, N.: Reasons for the loss and degradation of Australian wetlands, Wetl. Ecol. Manag., 7, 1-11, 1999.

Freeman, C., Lock, M., and Reynolds, B.: Fluxes of $\mathrm{CO}_{2}, \mathrm{CH}_{4}$ and $\mathrm{N}_{2} \mathrm{O}$ from a Welsh peatland following simulation of water table draw-down: Potential feedback to climatic change, Biogeochemistry, 19, 51-60, 1992.

GTCC: Cattai Wetlands Future Directions Strategy, available at: https://www.midcoast.nsw.gov.au/files/assets/public/ document-resources/council/projects-documents/big-swamp/ cattai-wetlands-future-directions-strategy-adopted-may-14. pdf (last access: 10 March 2018), 2014.

Hemes, K. S., Chamberlain, S. D., Eichelmann, E., Knox, S. H., and Baldocchi, D. D.: A biogeochemical compromise: The high methane cost of sequestering carbon in restored wetlands, Geophys. Res. Lett., 45, 6081-6091, 2018.

Henneberg, A., Sorrell, B. K., and Brix, H.: Internal methane transport through Juncus effusus: experimental manipulation of morphological barriers to test above-and below-ground diffusion limitation, New Phytol., 196, 799-806, 2012.

Holmkvist, L., Ferdelman, T. G., and Jørgensen, B. B.: A cryptic sulfur cycle driven by iron in the methane zone of marine sediment (Aarhus Bay, Denmark), Geochim. Cosmochim. Ac., 75, 3581-3599, 2011.

Jeffrey, L.: Rhizosphere to the atmosphere: contrasting methane pathways, fluxes, and geochemical drivers across the terrestrial- aquatic wetland boundary, Mendeley Data, v1, available at: https: //data.mendeley.com/datasets/st4vyjc73f/1, last access: 24 April 2019.

Jeffrey, L. C., Maher, D. T., Santos, I. R., McMahon, A., and Tait, D. R.: Groundwater, Acid and Carbon Dioxide Dynamics Along a Coastal Wetland, Lake and Estuary Continuum, Estuar. Coast., 39, 1325-1344, 2016.

Jeffrey, L. C., Maher, D. T., Johnston, S. G., Kelaher, B. P., Steven, A., and Tait, D. R.: Wetland methane emissions dominated by plant-mediated fluxes: Contrasting emissions pathways and seasons within a shallow freshwater subtropical wetland, Limnol. Oceanogr., https://doi.org/10.1002/lno.11158, 2019.

Johnston, S. G., Slavich, P. G., Sullivan, L. A., and Hirst, P.: Artificial drainage of floodwaters from sulfidic backswamps: effects on deoxygenation in an Australian estuary, Mar. Freshwater Res., 54, 781-795, 2003.

Johnston, S. G., Slavich, P. G., and Hirst, P.: The effects of a weir on reducing acid flux from a drained coastal acid sulphate soil backswamp, Agr. Water Manage., 69, 43-67, 2004.

Johnston, S. G., Keene, A. F., Burton, E. D., Bush, R. T., and Sullivan, L. A.: Quantifying alkalinity generating processes in a tidally remediating acidic wetland, Chem. Geol., 304, 106-116, 2012.

Johnston, S. G., Burton, E. D., Aaso, T., and Tuckerman, G.: Sulfur, iron and carbon cycling following hydrological restoration of acidic freshwater wetlands, Chem. Geol., 371, 9-26, 2014.

Karimian, N., Johnston, S. G., and Burton, E. D.: Acidity generation accompanying iron and sulfur transformations during drought simulation of freshwater re-flooded acid sulfate soils, Geoderma, 285, 117-131, 2017.

Karimian, N., Johnston, S. G., and Burton, E. D.: Iron and sulfur cycling in acid sulfate soil wetlands under dynamic redox conditions: A review, Chemosphere, 197, 803-816, https://doi.org/10.1016/j.chemosphere.2018.01.096, 2018.

Kim, J., Verma, S., Billesbach, D., and Clement, R.: Diel variation in methane emission from a midlatitude prairie wetland: significance of convective throughflow in Phragmites australis, Jo. Geophys. Res.-Atmos., 103, 28029-28039, 1998.

Kirschke, S., Bousquet, P., Ciais, P., Saunois, M., Canadell, J. G., Dlugokencky, E. J., Bergamaschi, P., Bergmann, D., Blake, D. R., Bruhwiler, L., Cameron-Smith, P., Castaldi, S., Chevallier, F., Feng, L., Fraser, A., Heimann, M., Hodson, E. L., Houweling, S., Josse, B., Fraser, P. J., Krummel, P. B., Lamarque, J.F., Langenfelds, R. L., Le Quéré, C., Naik, V., O’Doherty, S., Palmer, P. I., Pison, I., Plummer, D., Poulter, B., Prinn, R. G., Rigby, M., Ringeval, B., Santini, M., Schmidt, M., Shindell, D. T., Simpson, I. J., Spahni, R., Steele, L. P., Strode, S. A., Sudo, K., Szopa, S., van der Werf, G. R., Voulgarakis, A., van Weele, M., Weiss, R. F., Williams, J. E., and Zeng, G.: Three decades of global methane sources and sinks, Nat. Geosci., 6, 813-823, https://doi.org/10.1038/ngeo1955, 2013.

Knorr, K.-H., Glaser, B., and Blodau, C.: Fluxes and ${ }^{13} \mathrm{C}$ isotopic composition of dissolved carbon and pathways of methanogenesis in a fen soil exposed to experimental drought, Biogeosciences, 5, 1457-1473, https://doi.org/10.5194/bg-5-14572008, 2008.

Konnerup, D., Sorrell, B. K., and Brix, H.: Do tropical wetland plants possess convective gas flow mechanisms?, 
New Phytol., 190, 379-386, https://doi.org/10.1111/j.14698137.2010.03585.x, 2011.

Lal, R.: Carbon sequestration, Philos. T. R. Soc. B, 363, 815-830, 2008.

Melton, J. R., Wania, R., Hodson, E. L., Poulter, B., Ringeval, B., Spahni, R., Bohn, T., Avis, C. A., Beerling, D. J., Chen, G., Eliseev, A. V., Denisov, S. N., Hopcroft, P. O., Lettenmaier, D. P., Riley, W. J., Singarayer, J. S., Subin, Z. M., Tian, H., Zürcher, S., Brovkin, V., van Bodegom, P. M., Kleinen, T., Yu, Z. C., and Kaplan, J. O.: Present state of global wetland extent and wetland methane modelling: conclusions from a model intercomparison project (WETCHIMP), Biogeosciences, 10, 753788, https://doi.org/10.5194/bg-10-753-2013, 2013.

Milberg, P., Tornqvist, L., Westerberg, L. M., and Bastviken, D.: Temporal variations in methane emissions from emergent aquatic macrophytes in two boreonemoral lakes, AoB Plants, 9, plx029, https://doi.org/10.1093/aobpla/plx029, 2017.

Mitsch, W. J., Bernal, B., Nahlik, A. M., Mander, Ü., Zhang, L., Anderson, C. J., Jørgensen, S. E., and Brix, H.: Wetlands, carbon, and climate change, Landscape Ecol., 28, 583-597, 2013.

Moore, G. E., Burdick, D. M., Peter, C. R., and Keirstead, D. R.: Belowground biomass of Phragmites australis in coastal marshes, Northeast. Nat., 19, 611-627, 2012.

Mulvey, P.: Pollution, prevention and management of sulphidic clays and sands, Proceedings National Conference on Acid Sulphate Soils, edited by: Bush, R., 116-129, 1993.

Nedwell, D. B. and Watson, A.: $\mathrm{CH}_{4}$ production, oxidation and emission in a UK ombrotrophic peat bog: influence of $\mathrm{SO}_{4}^{2-}$ from acid rain, Soil Biol. Biochem., 27, 893-903, 1995.

Neubauer, S. C. and Megonigal, J. P.: Moving beyond global warming potentials to quantify the climatic role of ecosystems, Ecosystems, 18, 1000-1013, 2015.

Page, K. and Dalal, R.: Contribution of natural and drained wetland systems to carbon stocks, $\mathrm{CO}_{2}, \mathrm{~N}_{2} \mathrm{O}$, and $\mathrm{CH}_{4}$ fluxes: an Australian perspective, Soil Res., 49, 377-388, 2011.

Pangala, S. R., Enrich-Prast, A., Basso, L. S., Peixoto, R. B., Bastviken, D., Hornibrook, E. R., Gatti, L. V., Marotta, H., Calazans, L. S. B., and Sakuragui, C. M.: Large emissions from floodplain trees close the Amazon methane budget, Nature, 552, 230, 2017.

Penhale, P. A. and Wetzel, R. G.: Structural and functional adaptations of eelgrass (Zostera marina L.) to the anaerobic sediment environment, Can. J. Bot., 61, 1421-1428, 1983.

Pereyra, A. S. and Mitsch, W. J.: Methane emissions from freshwater cypress (Taxodium distichum) swamp soils with natural and impacted hydroperiods in Southwest Florida, Ecol. Eng., 114, 46-56, 2018.

Petrescu, A. M., Lohila, A., Tuovinen, J. P., Baldocchi, D. D., Desai, A. R., Roulet, N. T., Vesala, T., Dolman, A. J., Oechel, W. C., Marcolla, B., Friborg, T., Rinne, J., Matthes, J. H., Merbold, L., Meijide, A., Kiely, G., Sottocornola, M., Sachs, T., Zona, D., Varlagin, A., Lai, D. Y., Veenendaal, E., Parmentier, F. J., Skiba, U., Lund, M., Hensen, A., van Huissteden, J., Flanagan, L. B., Shurpali, N. J., Grunwald, T., Humphreys, E. R., JackowiczKorczynski, M., Aurela, M. A., Laurila, T., Gruning, C., Corradi, C. A., Schrier-Uijl, A. P., Christensen, T. R., Tamstorf, M. P., Mastepanov, M., Martikainen, P. J., Verma, S. B., Bernhofer, C., and Cescatti, A.: The uncertain climate footprint of wetlands un- der human pressure, P. Natl. Acad. Sci. USA, 112, 4594-4599, https://doi.org/10.1073/pnas.1416267112, 2015.

Pfeifer-Meister, L., Gayton, L. G., Roy, B. A., Johnson, B. R., and Bridgham, S. D.: Greenhouse gas emissions limited by low nitrogen and carbon availability in natural, restored, and agricultural Oregon seasonal wetlands, PeerJ, 6, https://doi.org/10.7717/peerj.5465, 2018.

Poffenbarger, H. J., Needelman, B. A., and Megonigal, J. P.: Salinity influence on methane emissions from tidal marshes, Wetlands, 31, 831-842, 2011.

Postma, D. and Jakobsen, R.: Redox zonation: equilibrium constraints on the $\mathrm{Fe}(\mathrm{III}) / \mathrm{SO}_{4}$-reduction interface, Geochim. Cosmochim. Ac., 60, 3169-3175, 1996.

Rayment, G. and Higginson, F. R.: Australian laboratory handbook of soil and water chemical methods, Inkata Press Pty Ltd, Melbourne, Australia, 1992.

Sammut, J., White, I., and Melville, M.: Acidification of an estuarine tributary in eastern Australia due to drainage of acid sulfate soils, Mar. Freshwater Res., 47, 669-684, 1996.

Saunois, M., Bousquet, P., Poulter, B., Peregon, A., Ciais, P., Canadell, J. G., Dlugokencky, E. J., Etiope, G., Bastviken, D., Houweling, S., Janssens-Maenhout, G., Tubiello, F. N., Castaldi, S., Jackson, R. B., Alexe, M., Arora, V. K., Beerling, D. J., Bergamaschi, P., Blake, D. R., Brailsford, G., Brovkin, V., Bruhwiler, L., Crevoisier, C., Crill, P., Covey, K., Curry, C., Frankenberg, C., Gedney, N., Höglund-Isaksson, L., Ishizawa, M., Ito, A., Joos, F., Kim, H.-S., Kleinen, T., Krummel, P., Lamarque, J.-F., Langenfelds, R., Locatelli, R., Machida, T., Maksyutov, S., McDonald, K. C., Marshall, J., Melton, J. R., Morino, I., Naik, V., O’Doherty, S., Parmentier, F.-J. W., Patra, P. K., Peng, C., Peng, S., Peters, G. P., Pison, I., Prigent, C., Prinn, R., Ramonet, M., Riley, W. J., Saito, M., Santini, M., Schroeder, R., Simpson, I. J., Spahni, R., Steele, P., Takizawa, A., Thornton, B. F., Tian, H., Tohjima, Y., Viovy, N., Voulgarakis, A., van Weele, M., van der Werf, G. R., Weiss, R., Wiedinmyer, C., Wilton, D. J., Wiltshire, A., Worthy, D., Wunch, D., Xu, X., Yoshida, Y., Zhang, B., Zhang, Z., and Zhu, Q.: The global methane budget 2000-2012, Earth Syst. Sci. Data, 8, 697-751, https://doi.org/10.5194/essd-8-697-2016, 2016.

Sivan, O., Antler, G., Turchyn, A. V., Marlow, J. J., and Orphan, V. J.: Iron oxides stimulate sulfate-driven anaerobic methane oxidation in seeps, P. Natl. Acad. Sci. USA, 111, E4139-E4147, 2014.

Sorrell, B. K. and Boon, P. I.: Convective gas flow in Eleocharis sphacelata R. Br.: methane transport and release from wetlands, Aquat. Bot., 47, 197-212, 1994.

Stocker, T. F., Qin, D., Plattner, G.-K., Tignor, M., Allen, S. K., Boschung, J., and Midgley, P. M.: Climate Change 2013: The Physical Science Basis. Contribution of Working Group I to the Fifth Assessment Report of the Intergovernmental Panel on Climate Change, 1535 pp., in: Cambridge Univ. Press, Cambridge, UK, and New York, USA, 2013.

Tucker, G. C.: The genera of Arundinoideae (Gramineae) in the southeastern United States, J. Arnold Arboretum, 71, 145-177, 1990.

Tulau, M.: Acid Sulphate Soil Priority Management Areas on the Lower Hastings Camden Haven Floodplains, Department of Land and Water Conservation, Sydney, Australia, 1999. 
Villa, J. A. and Bernal, B.: Carbon sequestration in wetlands, from science to practice: An overview of the biogeochemical process, measurement methods, and policy framework, Ecol. Eng., 114, 115-128, https://doi.org/10.1016/j.ecoleng.2017.06.037, 2018.

Walker, P. H.: Seasonal and stratigraphic controls in coastal floodplain soils, Soil Res., 10, 127-142, 1972.

Wang, Z., Zeng, D., and Patrick, W. H.: Methane emissions from natural wetlands, Environ. Monit. Assess., 42, 143-161, 1996.

White, I., Melville, M., Wilson, B., and Sammut, J.: Reducing acidic discharges from coastal wetlands in eastern Australia, Wetl. Ecol. Manag., 5, 55-72, 1997.
Whiting, G. J. and Chanton, J. P.: Plant-dependent $\mathrm{CH}_{4}$ emission in a subarctic Canadian fen, Global Biogeochem. Cy., 6, 225-231, 1992.

Whiting, G. J. and Chanton, J. P.: Greenhouse carbon balance of wetlands: methane emission versus carbon sequestration, Tellus B, 53, 521-528, 2001.

Wong, V. N., Johnston, S. G., Bush, R. T., Sullivan, L. A., Clay, C., Burton, E. D., and Slavich, P. G.: Spatial and temporal changes in estuarine water quality during a post-flood hypoxic event, Estuar. Coast. Shelf S., 87, 73-82, 2010. 